\title{
Determinants of households' livelihood diversification strategies to adapt with natural disasters: Evidence from ecologically vulnerable haor region of Bangladesh
}

Mohammad Shamsul Hoq ( $\sim$ shamsul305@yahoo.com )

Bangladesh Agricultural Research Institute https://orcid.org/0000-0002-0884-1280

Md. Taj Uddin

Bangladesh Agricultural University

Shankar Kumar Raha

Bangladesh Agricultural University

Mohammad Ismail Hossain

Bangladesh Agricultural University

\section{Research Article}

Keywords: Haor households, Livelihood strategies, Natural disasters, Multinominal logistic regression, Bangladesh

Posted Date: December 17th, 2021

DOI: https://doi.org/10.21203/rs.3.rs-1066696/v1

License: @ (1) This work is licensed under a Creative Commons Attribution 4.0 International License. Read Full License 


\section{Abstract}

The haor region of Bangladesh is exposed to a variety of natural disasters such as flash floods, seasonal floods, droughts, riverbank erosions, embankment breaches due to climate change, which impacts the haor people's lives and livelihoods. The study aims to assess the various livelihood strategies adopted by the haor households, as well as the factors that influence their decision to pursue more environmentally friendly and sustainable livelihood strategies. The primary data from the 300 haor households in Kishoregonj, Netrokona and Sunamgonj districts were collected with a multi-stage stratified random sample technique taking 100 of each district. We provide inimitable insight into the analysis framework for understanding sustainable rural livelihood, as well as empirical evidence of how livelihood resources, livelihood strategies, and livelihood outcomes are strongly interrelated. The study classified households' economic activities into five distinct categories together with crop farming to cope with natural disasters. Among the livelihood options, crop plus livestock rearing is the most productive livelihood strategy for haor households. The findings revealed that the higher returning livelihood diversification strategies are significantly influenced by the household's head age and education, dependency ratio, land holdings, household assets value, access to credit, annual income, membership of any organization, home to road, market, and haor distances, communication during the dry season, duration of waterlogged, and agro-ecology. In order to change the local context and enable poor households to establish more profitable livelihood strategies, policies should aim to promote the significant determinants of livelihood strategies, as well as ensure livelihood assets, a strong infrastructure, and minimize natural disasters.

\section{Introduction}

Agriculture has suffered globally as a result of natural disasters due to climate change. Rural livelihood in wetlands (haor[1]) of Bangladesh is mainly dependent on agriculture. Agriculture-based livelihood is vulnerable to the effect of several nature-induced disasters such as flash floods, floods, droughts, riverbank erosions, and embankment damage especially in the haor ecosystem of Bangladesh (CIRDAP 2016; Ferdushi et al. 2019; Ahmad and Afzal 2020). Pre-monsoon heavy and intense rainfall in April and May causes flash floods in the northeastern region of Bangladesh, and during the monsoon, the region receives too much water due to excessive rainfall that typically begins in June and causes seasonal flooding. Riverbank erosions and embankment breaches are associated with the onrush of the river water during flash floods and seasonal floods (Hoq et al. 2021a). Droughts, on the other hand, are caused by insufficient rainfall during the dry season (Toufique and Islam 2014; Kamal et al. 2018; Salam et al. 2021). Over the years, climate change has appeared as a threat to the natural life and livelihood of the haor community (Rahman et al. 2018a).The haor delta of Bangladesh is lying below the northeastern Himalayan foothills very often faces heavy rainfall which causes flash floods and monsoon floods every year (Sarker et al. 2014; Alamgir et al. 2020). There are altogether 423 haors spread over seven northeastern districts of Bangladesh (Alam et al. 2010, Kamruzzaman and Shaw 2018), which are geographically isolated and ecologically vulnerable (Rabby et al., 2013; Seventh Fifth Year Plan, 2015-2020) and comprised an area of about 2.0 million hectares and accommodated about 19.4 million people (Sharma 2010; Kamruzzaman and Shaw 2018; Uddin et al. 2019). More than 28\% of the population in the haor areas lives below the poverty line which is significantly higher than the national average (20.5\%) of Bangladesh (BBS, 2019). Natural disasters are the main causes of poverty, which are aggravated by the inaccessibility of basic infrastructure and social services, inequity in resource acquisition, and poor access to natural resources (Parvin and Akteruzzaman 2012). These nature-induced climatic events and inconvenience intensify environmental degradation in developing countries, particularly in Sub-Saharan Africa, South Asia, and the Pacific (Rahut et al. 2014, 2017; Gebru et al. 2018; Abera et al. 2021). Even in developed countries like Central America and the United Kingdom, smallholder farmers are vulnerable to the negative effects of climate change, which has had a significant impact on crop production because smallholder farmers rely on it for both subsistence and income (Donatti et al. 2019; Wheeler and Lobley 2021). Therefore, as a developing country like Bangladesh, where agriculture plays a vital role in the economy by providing subsistence and income to a large portion of the society, climate change effects pose a serious economic risk, particularly to the inhabitants of such agro-ecology susceptible to the natural hazard (Bhowmik et al. 2021; Ferdushi et al. 2019). Therefore, livelihood diversification strategy is fairly important to adapt with the vulnerability of these natural disasters (Roy and Basu 2020, Zhou et al. 2021), as it is predominantly a risk management strategy; both adaptation of climatic shocks and coping after definite shocks (Pelling 1999; Ellis 2000; Brouwer et al. 2007; Gebru et al. 2018; Ahmad and Afzal 2020; Adnan et al. 2021). Livelihood strategy comprises the household's capabilities, income activities, and assets holding (natural, physical, human, financial, and social) that contribute to a means of living (Chambers and Conway 1992; Islam et al. 2013; Rahman and Hickey 2020). Rural households combine a diverse set of economic and social activities, which construct a portfolio of livelihood income-generating activities to meet and enhance sustainable rural livelihood outcomes (Davis et al. 2010; Jiao et al. 2017; Khatiwada et al. 2017; Uddin et al. 2018; Pagnani et al. 2020). According to Ellis (1998) livelihood diversification is a process where household member constructs a diverse set of activities to help them fight for their survival and improve their living standards. Rahut et al. (2014) showed the majority of rural households in rural Nepal perceive more than one activity or income source for their livelihood. Gebru et al. (2018) also found that farm households engaged in a diverse set of off-farm and non-farm activities to cope with climate change in the eastern Tigray region of Ethiopia. Due to the risk and uncertainty in agricultural production, farm income alone could not feed the ever-increasing population (Gebru et al. 2018). Consequently, an alternative way of increasing income during the lean period of farming is to find out that could be involved in various nonfarm activities which will facilitate the farm households' to lead a good life (Parvin and Akteruzzaman 2012). Amare and Simane (2017) pointed out that smallholder farmers in the Blue Nile basin of Ethiopia adopt livelihood diversification as an adaptation strategy to climate change and variability. Uddin et al. (2021) also proposed a livelihood strategy approach for post-disaster risk management in coastal Bangladesh. Empirical research reveals that five livelihood strategies along with crop farming were pursued by the household in Rural Cambodia (Jiao et al. 2017), Nepal (Rahut et al. 2014), and Bhutan (Rahut et al. 2017) in different agro-ecological settings. In this study, livelihood diversification refers to the attempts by individuals and households to find new ways rather than a single activity to raise incomes and reduce vulnerability to different livelihood shocks in haor areas. The wetlands have various ecological, economical, and commercial importance to the residents as they are rich in biodiversity having rich flora and fauna (Kamruzzaman and Shaw 2018). The unwavering natural resources are land, forest, and water in the haor areas (Rana et al. 2009). Natural grazing land (grassland) and large water basins are made available to the haor community for income-generating, livestock rearing, and fisheries activities (Rana et al. 2009; Rabby et al. 2013). Despite the economic importance, the people in this region are poorer than in any other part of the country. However, agriculture (mainly rice cultivation) is 
highly seasonal farming in the haor areas of Bangladesh (Khan and Islam 2005; Gautam and Andersen 2016; Blackmore et al. 2021). During winter, paddy is produced with minimum effort while during monsoon the same is turned into a water basin which is a breeding place for fishery and a wide range of water biodiversity (Sheuli 2017). Generally, monsoon is the lean season for agriculture because all infrastructures, including road networks in the haor areas, are submerged for about 6-7 months (BHWDB 2012; CAN 2017). Therefore, this season offers a window of opportunities to the haor household to have interaction in several farms or off-farm activities i.e. fishing, poultry raising (mainly duck raising), and off-farm activities like wage laborer, boating, and small scale business for sustaining their livelihood (Islam et al. 2012; Rabby et al. 2013; Gautam and Andersen 2015; Trina et al. 2015; Alam et al. 2017; Akter et al. 2020). Different livelihood diversification strategies require a different level of investment and offer differential earnings. The poor households are less likely to get involved in higher returning sectors as it demands higher capital (human, social or financial capital) investment to start up (Gautam and Andersen 2016). As the majority of the haorhouseholds are living below the poverty line, it is crucial to explore and develop an in-depth understanding of the causes of poverty and vulnerability issues in the haor areas and how they manage their day to day activities as a part of the process of attempting to secure a sustainable livelihood. Previous study outside from Bangladesh consistently showed that diversification to the non-farm sector improves farm household incomes, enhance food security, and boosts agricultural productivity by reducing capital constraints and assisting in the management of environmental hazards (Barrett et al. 2001; Davis 2014; Loison 2015; Gebru et al. 2018). Livelihood activities of the haor household traditionally included irrigated boro rice cultivation, combined with homestead vegetable gardening, livestock rearing, fishing, poultry farming, and off-farm income activities i.e. small business, boating, day laborer (agricultural and non-agricultural), and household work as sources of subsistence (Hoque et al. 2018; Islam et al. 2016a; Islam et al. 2016b). Boro rice is grown on $80 \%$ of the haorareas, and it is frequently harmed by early flash floods, hailstorms, and drought (Alam et al. 2010; Ali et al. 2019). The flood risk is a great hazard for boro rice cultivation which trends to food insecurity of haor households because boro rice is the foremost source of year-round food supply for their livelihood (Ferdushi et al. 2019; Kabir et al. 2020). Fish culture is the second most important livelihood strategy after crop farming (rice) in Bangladesh and its production contributes to the livelihoods and employment of millions of people (Islam et al. 2012; Sunny 2017). Another lucrative livelihood strategy of haor household is livestock rearing in the haor areas during the dry season as it has large grazing land (Islam et al. 2016c). Due to ecological and geographical difficulties, the monsoon in the haor area is not suitable for livestock rearing. But during monsoon, duck rearing is a profitable option for the haor household because of the ecological support (Islam et al. 2016c). Homestead duck and chicken eggs are available in the local market and they earn a considerable amount of cash income for their livelihood (Huque et al. 2011). So, adopting context-based livelihood diversification strategies could be able to meet the present challenges of diversification, thus attaining household food security and improving livelihood security (Abera et al. 2021; Gebru et al. 2018). Most previous studies focused on the different issues, such as socioeconomic status, cropping patterns, livelihood vulnerability to flooding (i.e., livelihood exposure and sensitivity), and adaptation perspectives of the haor household, which justified the rationale for the study to be undertaken (Basak et al.2015; Dewan 2015; Rahman et al. 2018b; 2018c; Uddin et al. 2019; Hoq et al. 2021a). Only a limited number of studies were conducted on livelihood strategies and most of them concentrated on a single practice (Trina et al. 2015; Islam et al. 2016b; 2016c; Sunny 2017). Despite the significance of these studies, questions about how frequently and under what socioeconomic conditions diversification can take place remain unanswered. As a result, the focus of this research is to fill that gap by combining all possible livelihood strategies that can lead to livelihood diversification.

[1] A haor is a wetland ecosystem that physically is a bowl or saucer shaped shallow depression.

\section{Materials And Methods}

\subsection{Description of the Study area}

The research was carried out in the haor areas of Bangladesh, which are situated in the northeastern part of the country. The haor region's climate is subtropical monsoonal, with an annual rainfall of around $4,000 \mathrm{~mm}$. The monsoon season, which runs from June to October, yields almost $80 \%$ of the rainfall. Pre-monsoon temperatures range from $26^{\circ} \mathrm{C}$ to $31^{\circ} \mathrm{C}$ (March to May), rainy season temperatures range from $28^{\circ} \mathrm{C}$ to $31^{\circ} \mathrm{C}$, and winter temperatures range from $26^{\circ} \mathrm{C}$ to $27^{\circ} \mathrm{C}$ (Banglapedia 2003). The haor areas are spread over seven districts of Bangladesh; Sunamganj, Habiganj, Moulvibazar, Sylhet, Kishoreganj, Netrokona, and Brahmanbaria. Three dense haor districts (Kishoreganj, Sunamganj, and Netrokona) were purposively chosen from seven haor based districts and two administrative sub-units of each district (Upazila) were selected from each district, giving priority to the core haor area. The six administrative sub-units (Upazila) were Itna and Mithamoin in Kishoreganj, Khaliajuri and Mohonganj in Netrokona, and Derai and Salla in Sunamganj district (Fig. 1).

\subsection{Determination of sample size}

A total of 300 haor households with 100 from each district were surveyed from six Upazilas in three districts to collect primary data for reaching the study's objectives. Based on the household size of each Upazila, 50 potential farmers were selected from the union level (local level administrative unit) given priority for an equal distribution of six Upazila. The sample size was determined by following the given formula by Kothari (2004)

$$
n=\frac{p *(1-p) * Z^{2}}{e^{2}}(1)
$$

Where $\mathrm{n}$ is the sample size and $\mathrm{P}$ is the estimated proportion of respondents, 0.5 was used as a $\mathrm{p}$-value to get a maximum number of the respondents. $\mathrm{Z}$ denotes the amount of standard error in the $95 \%$ confidence interval, which is 1.96 , and e denotes the margin of error that the researchers are willing to accept, which is 0.06 .

$$
n=\frac{0.5 *(1-0.5) * 1.96^{2}}{0.06^{2}}=266 \approx 300
$$

Page $3 / 25$ 
Therefore, a complete of 300 households was selected from five livelihood strategy group (Table 1). The sample household picked proportionally from each livelihood strategy group.

Table 1

Livelihood strategies of the sample household

\begin{tabular}{|c|c|c|c|}
\hline Livelihood strategy group & Total households in the surveyed unions of six Upazila $(\mathrm{N})$ & Sample household (n) & Percent \\
\hline Group Y1: Only crop farming & 7361 & 102 & 34 \\
\hline Group Y2: Crop + Livestock farming & 3753 & 52 & 17 \\
\hline Group Y3: Crop + Fish farming & 3392 & 47 & 16 \\
\hline Group Y4: Crop + Poultry farming & 3248 & 45 & 15 \\
\hline Group Y5: Crop + Off-farm activities & 3897 & 54 & 18 \\
\hline Total & 21651 & 300 & 100 \\
\hline
\end{tabular}

\subsection{Data sources and data collection procedure}

This study relies on farm-level primary data collected from September 2019 to March 2020, with secondary information used only to compare the research findings. A pre-tested, semi-structured questionnaire was used to collect primary data from 300 haor households. Secondary data obtained from earlier research into the subject helped the researcher better understand the research area, shaping the research approach and identifying gaps that need to be filled by the research. Secondary information on relevant issues was gathered from various published sources, such as the Bangladesh Bureau of Statistics (BBS), the Upazila Agricultural Office (UAO), the Department of Agricultural Extension (DAE), and many others. Face-to-face interviews were conducted with the household head by trained enumerators with Bangladeshi linguistic communication (Bengali) for collecting primary data.

\subsection{Sampling technique and sampling procedure}

Multi-stage stratified sampling technique was used to select study location and sample households. In the first stage of sampling, the study locations were selected purposively, keeping in the mind of the geographical location and core haor area. The second stage involved the identification of five livelihood strategy groups, which was mostly practiced by the haor household. The numbers of sample households from each group are determined proportionately based on total household's number in the respective group. Finally, required numbers of sample households were selected randomly from each livelihood strategy group.

\subsection{Analytical framework to understand sustainable rural livelihood}

The sustainable livelihood concept is gradually important in the development context. The Sustainable Livelihood Framework (SLF) offers a strategy to reduce poverty through investigating the lives of poor people (Agarwala et al. 2014). The capabilities, tangible and intangible assets, and activities are needed to make a living can be defined as a livelihood. It will be called sustainable when it can survive with and recover from shocks and stress, and uphold its capabilities and assets, including the natural resource both presently and in the future. The sustainable livelihood framework (Fig. 2) is useful for determining whether people's livelihoods are sustainable in terms of three key aspects (Khatiwada et al., 2017; Carney, 1998; Soltani et al., 2012; Babulo et al., 2008). These are livelihood assets (human, natural, physical, financial, and social capitals), as well as mediating factors, livelihood diversification strategies, and outcomes that work together. However, the three aspects of the SLF are livelihood platform, livelihood strategy, and outcome (Fig. 2). Human, natural, physical, financial, and social capitals are the five categories of a household's assets highlighted by the SLF. Households combine these assets together with activities and choices and construct a portfolio of activities (such as crops, livestock, poultry, fisheries, etc.) to achieve their livelihood goals which can be defined as livelihood strategies. Households' livelihood strategy choice is influenced by its asset holding and external factors such as geographical location and infrastructure. This study also used household asset holding, geographical location (agro-ecology, waterlogging), and infrastructure (proximity to road and market center, communication system, etc.) as conditioning factors for livelihood strategy choice (Tesfaye et al., 2011; Soltani et al., 2012). Livelihood outcomes are the gains from livelihood strategies (such as income, food security, poverty reduction, environmental sustainability, etc.)

\subsection{Empirical Econometric model to understand determinant of livelihood strategy}

When the dependent variable has more than two choices, multinomial logistic regression (MNL) is a popular and widely used model for nominal outcomes (wulff 2014). According to Green (2003) when the dependent variable has more than two alternatives from which the decision-maker must choose (i.e., unordered qualitative) the appropriate econometric model is either multinomial logit or multinomial probit regression. However, due to the estimation difficulties imposed by the need to solve multiple integrations related to multivariate normal distributions, multinomial probit is rarely used in empirical investigations. Therefore, a multinomial logit model was used in the study to determine the factors that influence a haor household's decision to participate in various livelihood strategies (Abera et al. 2021; Gebru et al. 2018; Amare and Simane 2017). This model was chosen not only for its computational simplicity, but also for its greater ability to anticipate livelihood diversification and differentiate between rural households' livelihood strategies (Amare and Simane 2017). The dependent variables of the multinomial logistic regression are polytomous and allow more than two discrete outcomes. It can be used 
to analyze socioeconomic and physical explanatory variables empirically. A logical household head selects one of five livelihood strategy that provides the most utility. Assume for the $\mathrm{i}^{\text {th }}$ respondent faced with $\mathrm{j}$ choices, we specify the utility choice $\mathrm{j}$ as:

$$
U_{i j}=Z_{i j} \beta+\epsilon_{i j}(2)
$$

$\mathrm{U}_{\mathrm{ij}}$ is the highest of the $\mathrm{j}$ utility values if the respondent prefers choice $\mathrm{j}$. As a result, for $\mathrm{j}$ selection, the statistical probability model is:

$$
\operatorname{Prob}\left(U_{i j}>U_{i k}\right) \text { forallotherk } \neq j(3)
$$

Where,

$\mathrm{U}_{\mathrm{ij}}$ represents the utility of the $\mathrm{i}^{\text {th }}$ respondent from $\mathrm{j}^{\text {th }}$ livelihood strategy and $\mathrm{U}_{\mathrm{ik}}$ represents the utility of the $\mathrm{i}^{\text {th }}$ respondent from $\mathrm{k}^{\text {th }}$ livelihood strategy.

If a household's utility is calculated in terms of income realizations, then its option is simply an optimal allocation of its assets endowment to select a livelihood that maximizes its utility (Brown et al. 2006). Thus, the decision of the $\mathrm{i}^{\text {th }}$ household can be modeled in terms of optimizing expected utility by selecting the $\mathrm{j}^{\text {th }}$ livelihood strategy from a set of $\mathrm{J}$ discrete livelihood strategies, thus the choice function is:

$$
\max _{i}=E\left(U_{i j}\right)=\int\left(x_{i}\right)+\epsilon_{i j}, j=0 \ldots . J(4)
$$

If the $\mathrm{i}^{\text {th }}$ household chooses the $\mathrm{j}^{\text {th }}$ livelihood strategy to maximize its utility, the value could be 1 if the $\mathrm{i}^{\text {th }}$ household chooses the $\mathrm{j}^{\text {th }}$ livelihood strategy and 0 for otherwise. Thus, the probability of $\mathrm{i}^{\text {th }}$ household with $\mathrm{x}$ characteristics of $\mathrm{j}$ livelihood strategy are:

$\mathrm{P}_{\mathrm{ij}}=\frac{\exp \left(\mathrm{x}_{\mathrm{i}} \beta_{\mathrm{j}}\right)}{\sum_{\mathrm{j}}^{\mathrm{J}} \exp \left(\mathrm{x}_{\mathrm{i}} \beta_{\mathrm{j}}\right)}, \mathrm{J}=0(5)$

With the requirement that $\sum_{\mathrm{j}}^{\mathrm{J}} \mathrm{P}_{\mathrm{ij}}=1$ for any $\mathrm{i}$

Where;

$P_{i j}=$ Probability of $i^{\text {th }}$ respondent's chance of falling into category $j$,

$\mathrm{X}=$ Predictors of response probabilities and

$\beta_{j}=$ Covariate effect specific to $j^{\text {th }}$ responses category with the first reference category. The assumption that $\beta_{1}=0$ is an acceptable normalization that eliminates an indeterminacy in the model. This arises because probabilities sum to 1 , so only $\mathrm{J}$ parameter vectors are needed to determine the $\mathrm{J}+1$ probability (Galab et.al, 2002), so that $\exp \left(X_{i} \beta_{1}\right)=1$, implying that the above generalized Eq. (5) is equivalent to:

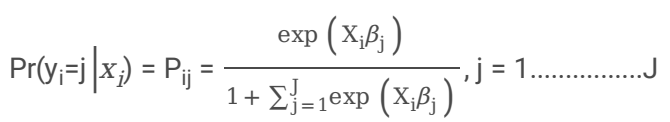

And

$\operatorname{Pr}\left(\mathrm{y}_{\mathrm{i}}=\mathrm{j} \mid x_{\mathrm{i}}\right)=\mathrm{P}_{\mathrm{i} 1}=\frac{1}{1+\sum_{\mathrm{j}=1}^{\mathrm{J}} \exp \left(\mathrm{x}_{\mathrm{i}} \beta_{\mathrm{j}}\right)}(6)$

Where;

$y=$ represents a polytomous outcome variable with codes ranging from $0 \ldots \ldots . . . J$

The restriction that the $\mathrm{J}$ probabilities sum to 1 yields the likelihood of $\mathrm{p}_{\mathrm{i} 1}$

That is $\mathrm{P}_{\mathrm{i} 1}=1-\sum P_{i j}$.

We can compute $\mathrm{J}$ log-odds ratios, which are defined as in the binary logit model, specified as:

$\ln \left[\frac{\mathrm{P}_{\mathrm{ij}}}{\mathrm{P}_{\mathrm{iJ}}}\right]=\mathrm{x}(\beta \mathrm{j}-\beta \mathrm{J})=\mathrm{x} \beta \mathrm{j}$, ifJ $=0(7)$

This type of discrete outcome model can be estimated by applying the maximum likelihood method.

Marginal effects must be determined if reasonable conclusions about the direction and magnitude of the relationship between an independent and dependent variable in an MNL are to be drawn (Bowen and Wiersema, 2004). The marginal effects of a continuous independent variable are:

Page $5 / 25$ 


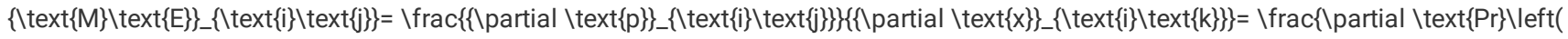

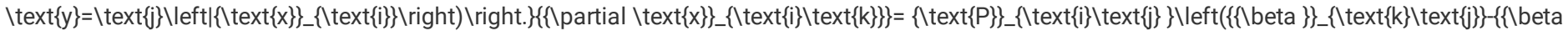
\}\}_\{ltext\{i\}\}\right) \left(8\right)

\subsection{Variables used in the model and their definition}

Five livelihood strategies groups were identify from the haor household and these were used as the dependent variables. It was assumed that the livelihood strategy choice is a function of several livelihood platform variables including a household's demographic factors, assets pentagon (human, natural, physical, financial, and social capitals) and location and geographical factors. Therefore, understanding the rural background of the haor inhabitants and reviewing the relevant literature, the explanatory variables as shown in Table 2 are selected for this study. The selected variables, their definitions, and expected relationships to livelihood strategy choices are summarized in Table 2. 
Table 2

Variables used, their definition, and expected relation with livelihood diversification strategies

\begin{tabular}{ll}
$\begin{array}{l}\text { Dependent } \\
\text { variable }\end{array}$ & Definition of variable \\
\hline $\begin{array}{l}\text { Livelihood } \\
\text { strategies }\end{array}$ & $\mathrm{C}=$ Crop farming \\
$\mathrm{Y}_{1}=\mathrm{C}$ & $\mathrm{C}+\mathrm{L}=$ Crop + Livestock farming \\
$\mathrm{Y}_{2}=\mathrm{C}+\mathrm{L}$ & $\mathrm{C}+\mathrm{F}=$ Crop + Fish farming \\
$\mathrm{Y}_{3}=\mathrm{C}+\mathrm{F}$ & $\mathrm{C}+\mathrm{P}=$ Crop + Poultry farming \\
$\mathrm{Y}_{4}=\mathrm{C}+\mathrm{P}$ & (Wage earner, petty business/enterprise) \\
$\mathrm{Y}_{5}=\mathrm{C}+\mathrm{Off}-\mathrm{Farm}$ & \\
\hline
\end{tabular}

\section{Expected relationship with livelihood strategies}

Five dominant livelihood strategies were found in the study areas to lead their livelihood

\section{Explanatory}

variable's

Human capital

Gender of $\mathrm{HH} \quad$ The gender is main decision maker of a $\mathrm{HH}$ (Dummy, if sex of household

head

head is male 1 , otherwise 0 )

Age of $\mathrm{HH}$ head Age of $\mathrm{HH}$ head in years

Education of Schooling years of $\mathrm{HH}$ head

$\mathrm{HH}$ head

Family size Total $\mathrm{HH}$ member

Dependency The dependency ratio is equal to the number of individuals aged below 15

ratio

$$
\text { as a percentage. }
$$

Agricultural $\quad \mathrm{HH}$ head or other members of the $\mathrm{HH}$ have training related to agriculture training

$$
\text { (Dummy, if Yes }=1, \text { No }=0 \text { ) }
$$

Skill $\quad \mathrm{HH}$ head or any member of the $\mathrm{HH}$ have training related to income

development generating activities (Dummy, if Yes $=1, \mathrm{No}=0$ )

training

Natural capital

Total land $\quad \mathrm{HH}$ total own agricultural land (ha)
holdings

Physical capital

Household assets value

Estimated value of building, agricultural and non-agricultural assets own by HH (BDT.)

Financial

capital

Access to credit $\quad \mathrm{HH}$ has getting loan facilities (Dummy; $\mathrm{Yes}=1, \mathrm{No}=0$ )

Income HH's total annual income (BDT.)

Expenditure $\quad$ HH's total annual expenditure (BDT.)

Social capital

Membership of

any

HH head or any member

organization

(Dummy; Yes $=1, \mathrm{No}=0$ )

Infrastructures

Home to road distance

Distance to nearest possible vehicle passable road $(\mathrm{km})$
Household headed by male are more likely to be involved in higher returning LDS

Younger $\mathrm{HH}$ heads are expected to adopt more profitable LDS

Higher educated $\mathrm{HH}$ heads are more likely to be involved in higher returning LDS

Household with a bigger family size are expected to be adopt farm-based LDS

Household having lower dependency are expected engaged more diversified activities.

$\mathrm{HH}$ having member/s with training related to agricultural training are expected to be involved in diversified agriculture

$\mathrm{HH}$ having member/s with skill development training are expected to be involved in self-employed rural enterprise.

$\mathrm{HH}$ with small agricultural land holdings are likely to diverted in non-farm or wage earner-based livelihood strategy

$\mathrm{HH}$ owning higher assets value are expected to engaged profitable LDS

distance 


\begin{tabular}{|c|c|c|}
\hline $\begin{array}{l}\text { Dependent } \\
\text { variable }\end{array}$ & Definition of variable & Expected relationship with livelihood strategies \\
\hline $\begin{array}{l}\text { Home to market } \\
\text { distance }\end{array}$ & Distance to nearest market place the $\mathrm{HH}$ usually used $(\mathrm{km})$ & $\begin{array}{l}\text { HH located closer to market places is more likely to } \\
\text { be market oriented farm and non-farm LDS }\end{array}$ \\
\hline $\begin{array}{l}\text { Home to haor } \\
\text { distance }\end{array}$ & Distance to nearest haor the HH usually effected by floodwater $(\mathrm{km})$ & $\begin{array}{l}\mathrm{HH} \text { located closer to nearby haor is less likely to be } \\
\text { engaged in diversified livelihood }\end{array}$ \\
\hline $\begin{array}{l}\text { Communication } \\
\text { during the } \\
\text { monsoon }\end{array}$ & $\begin{array}{l}\text { Ways of communication during monsoon } \\
\text { (Dummy; } 1=\text { Riverway, } 2 \text { = Roadway, and } 3 \text { = Both way ) }\end{array}$ & $\begin{array}{l}\text { The } \mathrm{HH} \text { who use the river as a means of } \\
\text { communication is more likely to be less diverse }\end{array}$ \\
\hline $\begin{array}{l}\text { Communication } \\
\text { during the dry } \\
\text { season }\end{array}$ & $\begin{array}{l}\text { Ways of communication during dry season } \\
\text { (Dummy; } 1=\text { Riverway, } 2 \text { = Roadway, and } 3 \text { = Both way ) }\end{array}$ & $\begin{array}{l}\mathrm{HH} \text { who use the road as a mode of transportation is } \\
\text { likely to be more diverse }\end{array}$ \\
\hline $\begin{array}{l}\text { Geographical } \\
\text { factors }\end{array}$ & & \\
\hline $\begin{array}{l}\text { Duration of } \\
\text { waterlogged }\end{array}$ & The average number of months that the land was waterlogged & $\begin{array}{l}\mathrm{HH} \text { facing higher the number of months is likely to } \\
\text { be less engaged in diversified strategies }\end{array}$ \\
\hline Agro-ecology & $\begin{array}{l}\text { Types of agricultural land in the haor areas (Dummy } 1=\text { low land, } 2= \\
\text { medium high land, and } 3=\text { high land) }\end{array}$ & $\begin{array}{l}\mathrm{HH} \text { in high land haor are expected to be involved in } \\
\text { higher returning LDSs }\end{array}$ \\
\hline
\end{tabular}

\section{Results}

\subsection{Household's income composition of different livelihood strategy}

This study identified haor households into five livelihood strategy groups based on the haor household's existing livelihood activities. The Majority (34\%) of the haor households are engaged in only crop farming, particularly rice agriculture, which is unprofitable but has to continue due to their forefathers' profession (Hoq et al., 2021a). Crop plus off-farm activities employed approximately $18 \%$ of households, followed by crop plus livestock farming (17.33\%), crop plus fish farming (15.67\%), and crop + poultry farming (15\%) (Table 1). The sources of income for the various livelihood strategy groups are shown in Table 3. Rice, vegetables, oilseeds, maize, livestock, fisheries, poultry, wage/salary, petty business, vehicle driving, boating, power tiller operation, remittances, and land rent were all divided into fourteen categories. Crop farming is to be considered as a major component for all five categories of livelihood strategy group because about $80 \%$ of haor households depend on rice-based agriculture. Households in group Y1 exclusively depend on crop farming. Rice is the main crop for all types of livelihood strategies which contributes $91 \%$ of total income for group $Y 1$ followed by $70 \%$ for group $Y 2,57 \%$ for group Y3, 43\% for group Y4, and 64\% for group Y5. Households of the livelihood strategy group Y2 are involved in a combination of crop farming and livestock rearing which is the most lucrative earning source in the haor area and livestock alone contribute $28 \%$ of total income (Table 3 ). Households in groups $\mathrm{Y} 3$ and $\mathrm{Y} 4$ allocate their resources to fisheries and poultry farming in addition to crop farming respectively and fisheries and poultry farming alone contribute $34 \%$ and $50 \%$ of total income respectively. Commercial duck rearing by income group Y4 plays an important role to achieve such a percentage. Households in livelihood strategy group Y5 are the most diversified as they engage in different off-farm activities that in addition to crop farming. The households of this strategy generally pursued different off-farm activities such as wage and salary (13\%), petty business (15\%), vehicle driving (2\%), and remittances (4\%) which contribute altogether $34 \%$ of total annual income. The average annual income of different livelihood strategy groups is shown in Fig. 3. The highest annual average income is found in pursuing crop plus livestock farming (BDT.4,81,398) followed by crop plus fish farming (BDT. $4,09,622)$, crop plus poultry farming (BDT. 4,09,509), crop plus off-farm activities (BDT.3,05,433), and only crop farming (BDT. 235864). Hence, crop plus livestock farming is the most profitable livelihood strategy, on the other hand only crop farming is the least profitable livelihood strategy in the haor areas of Bangladesh. 
Table 3

Source and accounting of income by livelihood strategies

\begin{tabular}{|c|c|c|c|c|c|c|c|c|c|c|}
\hline \multirow[t]{2}{*}{$\begin{array}{l}\text { Income } \\
\text { sources }\end{array}$} & \multicolumn{2}{|c|}{$\mathrm{Y} 1=$ crop farming } & \multicolumn{2}{|c|}{$\begin{array}{l}\text { Y2= Crop + Livestock } \\
\text { farming }\end{array}$} & \multicolumn{2}{|c|}{$\begin{array}{l}Y 3=\text { Crop + Fish } \\
\text { farming }\end{array}$} & \multicolumn{2}{|c|}{$\begin{array}{l}\text { Y4 = Crop + Poultry } \\
\text { farming }\end{array}$} & \multicolumn{2}{|c|}{$\begin{array}{l}\text { Y5 = Crop + Off-farm } \\
\text { activities }\end{array}$} \\
\hline & Tk./year/HH & $\begin{array}{l}\% \text { of } \\
\text { total } \\
\text { income }\end{array}$ & Tk./year/HH & $\begin{array}{l}\% \text { of } \\
\text { total } \\
\text { income }\end{array}$ & Tk./year/HH & $\begin{array}{l}\% \text { of } \\
\text { total } \\
\text { income }\end{array}$ & Tk./year/HH & $\begin{array}{l}\% \text { of } \\
\text { total } \\
\text { income }\end{array}$ & Tk./year/HH & $\begin{array}{l}\% \text { of } \\
\text { total } \\
\text { income }\end{array}$ \\
\hline \multicolumn{11}{|l|}{ Crops } \\
\hline Rice & 214820 & 91 & 335868 & 70 & 235494 & 57 & 177689 & 43 & 196187 & 64 \\
\hline vegetables & 6387 & 3 & 1105 & 0 & 10638 & 3 & 4644 & 1 & 1294 & 0 \\
\hline Oilseed & 0 & 0 & 0 & 0 & 0 & 0 & 0 & 0 & 252 & 0 \\
\hline Maize & 746 & 0 & 0 & 0 & 0 & 0 & 0 & 0 & 385 & 0 \\
\hline Livestock & & 0 & 134060 & 28 & & 0 & & 0 & 0 & 0 \\
\hline Fisheries & 0 & 0 & 0 & 0 & 140723 & 34 & 0 & 0 & 0 & 0 \\
\hline Poultry & 0 & 0 & 0 & 0 & & 0 & 206776 & 50 & 0 & 0 \\
\hline $\begin{array}{l}\text { Off-farm } \\
\text { Activities }\end{array}$ & & 0 & & 0 & & 0 & & 0 & & 0 \\
\hline Wage/salary & 0 & 0 & 0 & 0 & 0 & 0 & & 0 & 40889 & 13 \\
\hline $\begin{array}{l}\text { Petty } \\
\text { business }\end{array}$ & 0 & 0 & 0 & 0 & 0 & 0 & 0 & 0 & 46611 & 15 \\
\hline Driving & 0 & 0 & 0 & 0 & 0 & 0 & 0 & 0 & 5130 & 2 \\
\hline Boating & 0 & 0 & 0 & 0 & 0 & 0 & 0 & 0 & 1667 & 1 \\
\hline $\begin{array}{l}\text { PT } \\
\text { operating }\end{array}$ & 0 & 0 & 0 & 0 & 0 & 0 & 0 & 0 & 1481 & 0 \\
\hline Remittances & 0 & 0 & 0 & 0 & 0 & 0 & 0 & 0 & 11389 & 4 \\
\hline Land rent & 13912 & 6 & 10365 & 2 & 22766 & 6 & 20400 & 5 & 148 & 0 \\
\hline $\begin{array}{l}\text { Total } \\
\text { income }\end{array}$ & 235864 & 100 & 481398 & 100 & 409622 & 100 & 409509 & 100 & 305433 & 100 \\
\hline
\end{tabular}

\subsection{Descriptive statistics of the variables used in the model}

The descriptive statistics of the livelihood platform variables used in the analysis were shown in Table 4. As for human capital, the empirical results revealed that the percentage of female-headed households is the lowest for only crop plus fish farming strategy (2\%), while it was highest (15\%) for the crop plus poultry farming activities. Hence, a female-headed household is likely to pursue crop plus off-farm activities though the overall percentage of female-headed households is less likely in all kinds of livelihood strategies because of religious and cultural barriers. The average age of the head of household is highest for crop plus fish farming strategy (48.32 years) whereas it is 47.08 years for crop plus livestock farming, 44.53 years for only crop farming, 43.85 years for crop plus off-farm activities, and 42.87 years for crop plus poultry farming. It suggests that crop farming, supplemented by poultry farming and off-farm activities, is preferred by the relatively young household heads. The result indicates that education plays a vital role in livelihood diversification strategy more willingly than crop plus poultry farming. The large family size is observed in the case of the crop plus livestock farming (6.56) followed by crop plus fish farming (5.79), crop plus poultry farming (5.47), crop plus off-farm activities (5.43), and only crop farming (5.14), which implies that a number of a family member in a household significantly influence the choice of livelihood diversification strategy. As for indicators of human capital, the agricultural and skill development training has a similar pattern in the case of diversifying livelihood strategy. However, for the dependency ratio, a divergent trend was found in the choice of livelihood diversification choice. As for natural capital, the total arable land holding is the highest (2.20 ha) for the household engaged in crop plus livestock farming, whereas it was lowest (1.12 ha) for crop plus off-farm activities signifying that less arable land holdings are important divers of household diversifying into off-farm activities. As for physical capital, the household assets value is highest for crop plus livestock farming (BDT. 6,25,324) followed by crop plus fish farming (BDT. 365645.1), crop plus poultry farming (BDT. 281090.6), crop farming (BDT.190226.70), and crop plus off-farm activities (BDT. 186207.80). The financial capital comprises access to credit, annual income, and annual expenditure indicators of a household livelihood diversification strategy. The result shows that the percentage of households in access to credit indicator is the highest (0.57) for only crop farming and the lowest (0.37) for crop plus off-farm activities. We observed a similar pattern in the other two financial capital indicators while annual income and annual expenditure are the least for pursuing only crop farming livelihood strategy. Membership of any organization is an important indicator of social capital which is a driver of pursuing the highest profitable livelihood strategy that is crop plus livestock farming. The infrastructure indicators home to road distance $(0.58 \mathrm{~km})$ are the least and the home to market distance $(1.49 \mathrm{~km})$, home to haor distance $(1.45 \mathrm{~km})$ is the highest for pursuing in crop plus off-farm activities, indicating as important accessibility determinants for livelihood strategy. On the other hand, communication system such as river way or roadway or both ways play an important role in the diversification of livelihood strategy. Due to its 
geographical location, there is little difference in the value of the duration of waterlogging in the five types of the livelihood strategy group. The value of the agro-ecology indicators is the least for only crop farming, indicating the household in low land type agro-ecology mostly engaged in crop farming. 
Table 4

Descriptive statistic of the livelihood platform variables

\begin{tabular}{|c|c|c|c|c|c|c|c|c|c|c|}
\hline \multirow[t]{2}{*}{$\begin{array}{l}\text { Livelihood } \\
\text { platform } \\
\text { variable }\end{array}$} & \multicolumn{2}{|c|}{$Y_{1}=$ Only crop farming } & \multicolumn{2}{|c|}{$\begin{array}{l}Y_{2}=\text { Crop + Livestock } \\
\text { farming }\end{array}$} & \multicolumn{2}{|c|}{$\begin{array}{l}Y_{3}=\text { Crop + Fish } \\
\text { farming }\end{array}$} & \multicolumn{2}{|c|}{$\begin{array}{l}Y_{4}=\text { Crop + Poultry } \\
\text { farming }\end{array}$} & \multicolumn{2}{|c|}{$\begin{array}{l}Y_{5}=\text { Crop + Off-farm } \\
\text { activities }\end{array}$} \\
\hline & Mean & Std. Dev. & Mean & Std. Dev. & Mean & Std. Dev. & Mean & Std. Dev. & Mean & Std. Dev. \\
\hline \multicolumn{11}{|l|}{ Human capital } \\
\hline $\begin{array}{l}\text { Gender of } \mathrm{HH} \\
\text { head }\end{array}$ & 0.94 & 0.24 & 0.96 & 0.20 & 0.98 & 0.15 & 0.84 & 0.37 & 0.87 & 0.34 \\
\hline Age of $\mathrm{HH}$ head & 44.53 & 11.85 & 47.08 & 10.47 & 48.32 & 10.86 & 42.87 & 11.20 & 43.85 & 12.43 \\
\hline $\begin{array}{l}\text { Education of } \\
\mathrm{HH} \text { head }\end{array}$ & 4.83 & 3.94 & 5.79 & 4.07 & 5.38 & 4.32 & 4.76 & 3.85 & 5.61 & 3.96 \\
\hline Family size & 5.14 & 1.83 & 6.56 & 2.69 & 5.79 & 1.72 & 5.47 & 1.59 & 5.43 & 1.35 \\
\hline $\begin{array}{l}\text { Dependency } \\
\text { ratio }\end{array}$ & 1.55 & 0.53 & 1.51 & 0.44 & 1.46 & 0.38 & 1.71 & 0.67 & 1.63 & 0.51 \\
\hline $\begin{array}{l}\text { Agricultural } \\
\text { training }\end{array}$ & 0.33 & 0.47 & 0.52 & 0.50 & 0.49 & 0.51 & 0.33 & 0.48 & 0.24 & 0.43 \\
\hline $\begin{array}{l}\text { Skill } \\
\text { development } \\
\text { training }\end{array}$ & 0.25 & 0.44 & 0.44 & 0.50 & 0.51 & 0.51 & 0.27 & 0.45 & 0.20 & 0.41 \\
\hline \multicolumn{11}{|l|}{ Natural capital } \\
\hline $\begin{array}{l}\text { Total land } \\
\text { holdings }\end{array}$ & 1.27 & 1.23 & 2.20 & 3.41 & 1.53 & 1.29 & 1.14 & 0.87 & 1.12 & 0.86 \\
\hline \multicolumn{11}{|l|}{ Physical capital } \\
\hline $\begin{array}{l}\text { Household } \\
\text { assets value }\end{array}$ & 190226.70 & 191733.10 & 625324 & 478177.5 & 365645.1 & 290848.1 & 281090.6 & 159494.9 & 186207.80 & 136635.20 \\
\hline \multicolumn{11}{|l|}{$\begin{array}{l}\text { Financial } \\
\text { capital }\end{array}$} \\
\hline Access to credit & 0.57 & 0.50 & 0.56 & 0.50 & 0.45 & 0.50 & 0.40 & 0.50 & 0.37 & 0.49 \\
\hline Annual income & 235864.10 & 172188.20 & 481397.5 & 527586.7 & 409621.9 & 215382.9 & 409508.9 & 226657.3 & 305433.30 & 122993.30 \\
\hline $\begin{array}{l}\text { Annual } \\
\text { expenditure }\end{array}$ & 224450.80 & 110850.70 & 353241.7 & 157790.7 & 312561.2 & 142483.2 & 289806.00 & 94794.24 & 247817.20 & 75169.07 \\
\hline \multicolumn{11}{|l|}{ Social capital } \\
\hline $\begin{array}{l}\text { Membership of } \\
\text { any } \\
\text { organization }\end{array}$ & 0.20 & 0.40 & 0.50 & 0.50 & 0.38 & 0.49 & 0.31 & 0.47 & 0.26 & 0.44 \\
\hline \multicolumn{11}{|l|}{ Infrastructures } \\
\hline $\begin{array}{l}\text { Home to road } \\
\text { distance }\end{array}$ & 0.69 & 0.32 & 0.80 & 0.70 & 0.73 & 0.42 & 0.74 & 0.28 & 0.58 & 0.30 \\
\hline $\begin{array}{l}\text { Home to market } \\
\text { distance }\end{array}$ & 0.82 & 0.50 & 0.71 & 0.32 & 1.20 & 1.42 & 0.93 & 0.44 & 1.49 & 4.67 \\
\hline $\begin{array}{l}\text { Home to haor } \\
\text { distance }\end{array}$ & 1.17 & 0.82 & 1.26 & 0.95 & 1.15 & 0.90 & 1.37 & 1.43 & 1.45 & 1.29 \\
\hline $\begin{array}{l}\text { Communication } \\
\text { during } \\
\text { monsoon }\end{array}$ & 1.36 & 0.77 & 1.35 & 0.76 & 1.34 & 0.76 & 1.22 & 0.60 & 1.31 & 0.72 \\
\hline $\begin{array}{l}\text { Communication } \\
\text { during dry } \\
\text { season }\end{array}$ & 2.17 & 0.66 & 2.06 & 0.73 & 2.23 & 0.73 & 2.04 & 0.80 & 2.35 & 0.62 \\
\hline \multicolumn{11}{|l|}{$\begin{array}{l}\text { Geographical } \\
\text { factors }\end{array}$} \\
\hline $\begin{array}{l}\text { Duration of } \\
\text { waterlogged }\end{array}$ & 5.00 & 1.54 & 5.40 & 1.18 & 5.15 & 1.43 & 5.22 & 1.18 & 5.13 & 1.37 \\
\hline Agro-ecology & 1.47 & 0.52 & 1.75 & 0.76 & 1.81 & 0.65 & 1.53 & 0.63 & 1.59 & 0.66 \\
\hline
\end{tabular}


The results of MNL regression were presented in Table 5 . The study used only crop farming is as a base category to assess the effect of predictor variables

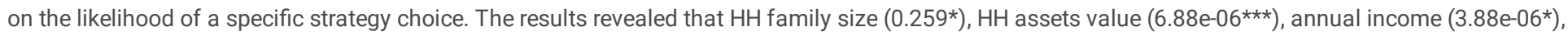

membership of any organization (1.517**), home to road distance $\left(1.867^{\star *}\right)$, riverway $\left(1.992^{\star *}\right)$ and both way (1.548**) (river and roadway) communication during the dry season, duration of the waterlogged condition $\left(0.600^{* *}\right)$, and comparatively high land (3.645***) type agro-ecology than low land had the positive and significant impact on choosing crop plus livestock farming than only crop farming. Likewise, some other variables such as total land holdings $\left(-1.151^{\star \star \star}\right)$ and home to market distance $\left(-1.805^{\star \star}\right)$ had a negative and significant influence on choosing crop plus livestock farming. While comparing the crop plus fish farming with only crop farming, $\mathrm{HH}$ head age $(0.039 *)$, total land holdings $\left(-1.025^{\star \star \star}\right)$, $\mathrm{HH}$ assets value $\left(2.59 \mathrm{e}-06^{\star \star}\right)$, annual income $(5.85 \mathrm{e}-$ $\left.06^{\star \star \star}\right)$, membership of any organization $(0.887 *)$, riverway communication during the dry season $\left(1.290^{\star}\right)$, and comparatively high land $\left(3.193^{\star \star \star}\right)$ type agro-ecology than low land had a significant influence on adopting the livelihood strategy of the crop plus fish farming. Similarly, households with a higher annual income $\left(8.62 \mathrm{e}-06^{\star \star *}\right)$, closer to the road connectivity $\left(1.231^{\star}\right)$, riverway $\left(1.924^{\star \star *}\right)$ communication during the dry season rather than roadway, duration of the waterlogged condition $(0.379 * \star)$, and generally high land $\left(2.704^{\star \star \star}\right)$ type agro-ecology compared to low land were more likely to adopt crop plus poultry farming rather than crop farming alone. On contrary, accessibility to credit $(-1.087 * \star)$, household total land holdings $\left(-1.426^{\star \star \star}\right)$, had a negative and significant influence on adopting crop plus poultry farming as a livelihood strategy. Crop plus off-farm activities are a very important part of the subsistence household, which includes a diverse range of activities. The households of that group were positively and significantly influenced by the $\mathrm{HH}$ head education $\left(0.128^{\star *}\right)$, annual income $\left(6.29 \mathrm{e}-06^{\star * *}\right)$, located closer to the haor $\left(0.552^{\star}\right)$, and high land (2.637**) type agro-ecology compared to low land

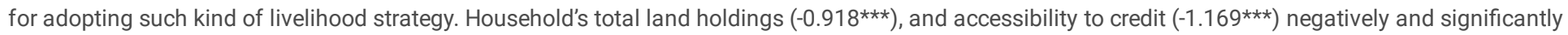
influences the household's decision on adopting crop plus off-farm activities. Due to the ecological characteristics of the haor areas, infrastructural and geographical factors have had a greater impact on the adoption of livelihood diversification strategies than socioeconomic variables. 
Table 5

Determinants of livelihood diversification strategies choice

\begin{tabular}{|c|c|c|c|c|}
\hline \multirow[t]{2}{*}{ Livelihood platform variables } & \multicolumn{4}{|c|}{$\begin{array}{l}\text { Livelihood diversification strategies } \\
\text { (Crop farming is a reference category) }\end{array}$} \\
\hline & $\begin{array}{l}Y_{2}=\text { Crop + Livestock } \\
\text { farming }\end{array}$ & $\begin{array}{l}Y_{3}=\text { Crop + Fish } \\
\text { farming }\end{array}$ & $\begin{array}{l}Y_{4}=\text { Crop + Poultry } \\
\text { farming }\end{array}$ & $\begin{array}{l}Y_{5}=\text { Crop + Off-farm } \\
\text { activities }\end{array}$ \\
\hline \multicolumn{5}{|l|}{ Human capital } \\
\hline \multirow[t]{2}{*}{ Gender of $\mathrm{HH}$ head } & 1.427 & 1.636 & -1.161 & -0.649 \\
\hline & $(1.169)$ & $(1.243)$ & $(0.778)$ & $(0.745)$ \\
\hline \multirow[t]{2}{*}{ Age of $\mathrm{HH}$ head } & 0.024 & $0.039 *$ & 0.010 & 0.015 \\
\hline & $(0.025)$ & $(0.021)$ & $(0.022)$ & $(0.019)$ \\
\hline \multirow[t]{2}{*}{ Education of $\mathrm{HH}$ head } & 0.088 & 0.083 & 0.067 & $0.128 * *$ \\
\hline & $(0.068)$ & $(0.060)$ & $(0.067)$ & $(0.060)$ \\
\hline \multirow[t]{2}{*}{ Family size } & $0.259 *$ & 0.001 & -0.154 & 0.106 \\
\hline & $(0.144)$ & $(0.133)$ & $(0.148)$ & $(0.134)$ \\
\hline \multirow[t]{2}{*}{ Dependency ratio } & -0.017 & -0.362 & 0.641 & 0.038 \\
\hline & $(0.562)$ & $(0.466)$ & $(0.419)$ & $(0.410)$ \\
\hline \multirow[t]{2}{*}{ Agricultural training } & 0.209 & -0.164 & -0.036 & -0.424 \\
\hline & $(0.631)$ & $(0.564)$ & $(0.585)$ & $(0.542)$ \\
\hline \multirow[t]{2}{*}{ Skill development training } & -0.243 & 0.658 & -0.635 & -0.751 \\
\hline & $(0.637)$ & $(0.570)$ & $(0.621)$ & $(0.594)$ \\
\hline \multicolumn{5}{|l|}{ Natural capital } \\
\hline \multirow[t]{2}{*}{ Total land holdings } & $-1.151^{\star \star \star}$ & $-1.025^{\star \star \star}$ & $-1.426 * \star \star$ & $-0.918 * \star \star$ \\
\hline & $(0.330)$ & $(0.291)$ & $(0.325)$ & $(0.295)$ \\
\hline \multicolumn{5}{|l|}{ Physical capital } \\
\hline \multirow[t]{2}{*}{$\mathrm{HH}$ assets value } & $6.88 \mathrm{e}-06 * \star \star$ & $2.59 \mathrm{e}-06^{\star \star}$ & $1.42 \mathrm{e}-06$ & $-1.45 e-06$ \\
\hline & $(1.28 \mathrm{e}-06)$ & $(1.21 \mathrm{e}-06)$ & $(1.39 e-06)$ & $(1.61 \mathrm{e}-06)$ \\
\hline \multicolumn{5}{|l|}{ Financial capital } \\
\hline \multirow[t]{2}{*}{ Access to credit } & -0.370 & -0.728 & $-1.087 * \star$ & 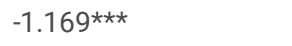 \\
\hline & $(0.547)$ & $(0.486)$ & $(0.487)$ & $(0.434)$ \\
\hline \multirow[t]{2}{*}{ Annual income } & $3.88 \mathrm{e}-06^{*}$ & $5.85 \mathrm{e}-06^{\star \star \star}$ & $8.62 \mathrm{e}-06^{\star \star \star}$ & $6.29 \mathrm{e}-06^{\star \star \star}(2.10 \mathrm{e}-06)$ \\
\hline & $(2.30 \mathrm{e}-06)$ & $(2.12 \mathrm{e}-06)$ & $(2.13 e-06)$ & \\
\hline \multirow[t]{2}{*}{ Annual expenditure } & $6.19 e-06$ & $4.78 \mathrm{e}-06$ & $3.33 e-06$ & $-1.39 e-06$ \\
\hline & $(4.01 \mathrm{e}-06)$ & $(3.79 \mathrm{e}-06)$ & $(3.94 \mathrm{e}-06)$ & $(3.96 e-06)$ \\
\hline \multicolumn{5}{|l|}{ Social capital } \\
\hline \multirow[t]{2}{*}{ Membership of any organization } & 1.517 *夫 & $0.887 *$ & 0.489 & 0.777 \\
\hline & $(0.597)$ & $(0.526)$ & $(0.591)$ & $(0.545)$ \\
\hline \multicolumn{5}{|l|}{ Infrastructures } \\
\hline \multirow[t]{2}{*}{ Home to road distance } & $1.867 * \star$ & 0.597 & $1.231 *$ & -0.929 \\
\hline & $(0.847)$ & $(0.693)$ & $(0.758)$ & $(0.763)$ \\
\hline \multirow[t]{2}{*}{ Home to market distance } & $-1.805^{\star \star}$ & 0.414 & -0.186 & 0.360 \\
\hline & $(0.716)$ & $(0.332)$ & $(0.477)$ & $(0.335)$ \\
\hline \multirow[t]{2}{*}{ Home to haor distance } & 0.495 & -0.100 & $(0.244)$ & $0.552^{*}$ \\
\hline & $(0.421)$ & $(0.361)$ & $(0.356)$ & $(0.324)$ \\
\hline
\end{tabular}




\begin{tabular}{|c|c|c|c|c|}
\hline \multirow[t]{2}{*}{ Livelihood platform variables } & \multicolumn{4}{|c|}{$\begin{array}{l}\text { Livelihood diversification strategies } \\
\text { (Crop farming is a reference category) }\end{array}$} \\
\hline & $\begin{array}{l}Y_{2}=\text { Crop + Livestock } \\
\text { farming }\end{array}$ & $\begin{array}{l}Y_{3}=\text { Crop + Fish } \\
\text { farming }\end{array}$ & $\begin{array}{l}Y_{4}=\text { Crop + Poultry } \\
\text { farming }\end{array}$ & $\begin{array}{l}Y_{5}=\text { Crop + Off-farm } \\
\text { activities }\end{array}$ \\
\hline Communication during monsoon & \multicolumn{4}{|c|}{ River way is reference category } \\
\hline \multirow[t]{2}{*}{ Road way } & -12.013 & -12.199 & 1.458 & -1.500 \\
\hline & $(1101.34)$ & $(736.12)$ & $(2.171)$ & $(2.473)$ \\
\hline \multirow[t]{2}{*}{ Both way } & -0.058 & 0.578 & -1.140 & -0.625 \\
\hline & $(1.025)$ & $(0.874)$ & $(1.032)$ & $(0.866)$ \\
\hline $\begin{array}{l}\text { Communication during dry } \\
\text { season }\end{array}$ & \multicolumn{4}{|c|}{ Road way is a reference category } \\
\hline \multirow[t]{2}{*}{ River way } & $1.992^{\star \star}$ & $1.290^{*}$ & 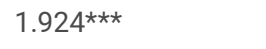 & 0.117 \\
\hline & $(0.812)$ & $(0.715)$ & $(0.704)$ & $(0.774)$ \\
\hline \multirow[t]{2}{*}{ Both way } & $1.548^{\star \star}$ & 0.824 & 0.539 & 0.777 \\
\hline & $(0.663)$ & $(0.552)$ & $(0.575)$ & $(0.501)$ \\
\hline \multicolumn{5}{|l|}{$\begin{array}{l}\text { Geographical and ecological } \\
\text { factors }\end{array}$} \\
\hline \multirow[t]{2}{*}{ Duration of waterlogged } & $0.600 \star \star$ & 0.197 & $0.379 \star \star$ & 0.052 \\
\hline & $(0.264)$ & $(0.182)$ & $(0.212)$ & $(0.144)$ \\
\hline Agro-ecology & \multicolumn{4}{|c|}{ Low land is a reference category } \\
\hline \multirow[t]{2}{*}{ Medium high land } & -0.824 & 0.469 & -0.313 & -0.318 \\
\hline & $(0.563)$ & $(0.470)$ & $(0.475)$ & $(0.432)$ \\
\hline \multirow[t]{2}{*}{ High land } & $3.645^{\star \star \star}$ & $3.193^{\star \star \star}$ & 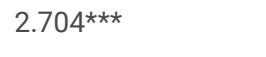 & $2.637 * \star$ \\
\hline & $(1.259)$ & $(1.216)$ & $(1.293)$ & $(1.192)$ \\
\hline \multirow[t]{2}{*}{ Constant } & $-13.545^{\star \star \star}$ & $-9.082^{\star \star \star}$ & 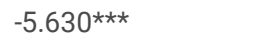 & -2.193 \\
\hline & $(3.150)$ & $(2.595)$ & $(2.404)$ & $(2.026)$ \\
\hline
\end{tabular}

(Note: Number of obs. $=300$, LR chi2 $(96)=297.20$, Prob > chi2 $=0.0000$, Log likelihood $=-317.66279$, Pseudo $\mathrm{R}^{2}=0.3187 ; * \star \star * \star * *$ indicates the $1 \%, 5 \%$ and $10 \%$ level of significance, figures in the parentheses indicate standard error)

\subsection{Diagnostic of the model}

The likelihood ratio statistics (-317.66279) of the multinominal logistic regression model as indicated by $\mathrm{x} 2$ statistics are highly significant ( $\mathrm{P}<0.0000)$, suggesting the model has strong explanatory power. The Hausman test for IIA, the seemingly unrelated postestimation procedure (SUEST), and the Small Hsiona based Husman test are used to diagnosis the model for the validity of the independence of the irrelevant alternatives (IIA) assumptions. The tests accept the null hypothesis of the independence of the livelihood strategy choice options, indicating that the multinomial logit (MNL) specification is appropriate to livelihood diversification strategy options practices by the haorhousehold. It was evident from $\chi 2$ value ranging from 0.119 to 3.342 in the case of the Hausman test (Appendix table A.1), $\chi 2$ value ranging from 34.18 to 74.462 in the case of SUEST (Appendix table A.2), and $\chi 2$ value ranging from 196.777 to 319.997 in case of Small Hsiona test (Appendix table A.3), which indicates there is no evidence that the independence of the irrelevant alternatives (IIA) assumption was violated. The higher the value of variance inflation factor (VIF), usually greater than 10 , the more serious the multicollinearity problem. The VIF value of the independent variables is less than the critical value of VIF (10) which justifies that there is no multicollinearity among the variables (Appendix table A.4). Moreover, the correlation matrix indicated that there is no severe multicollinearity problem in the fitted model (Appendix table A.5).

\subsection{Determinants of livelihood diversification strategy via marginal effect}

We may depend on another powerful interpretative technique: marginal effects after multinomial logistic regression to further make the results to our sense. The marginal effects help us to inform the change in predicted probabilities due to a change in a particular predictor (Bowen and Wiersema 2004; Roy and Basu 2020). A negative and significant coefficient of the gender of $\mathrm{HH}$ head indicates a negative relationship between gender of $\mathrm{HH}$ head and probability of adoption of a specific livelihood strategy (Table 6). For example, an increase by one male-headed HH would lead to a $20 \%$ decrease in the likelihood of adopting crop plus poultry farming. Education is an important influencing factor in adopting new improved agricultural technologies or information, which increased agricultural productivity (Abid et al. 2015; Elahi et al. 2015). In our study, the significant positive coefficient of education of the household head shows that the probability of accessing crop plus off-farm activities increase by $1 \%$ with an increase of one year of schooling compared to crop farming. A 
negative coefficient of family size indicates a negative relationship between family size and livelihood strategies choice (Khatun and Roy 2012), whereas a positive coefficient between dependency ratio and livelihood strategies indicates a positive relationship. Suppose, an addition by one individual in the household size is more likely to a decrease of $2.3 \%$ in the adoption of livelihood strategy Y4 (crop plus poultry farming). On contrary, an increase by one individual in the household size is more likely to an increase of $2.2 \%$ in the adoption of livelihood strategy $Y 2$ (crop plus livestock farming). In the case of dependency ratio, the livelihood strategy choice of Y4 (crop plus poultry farming) would increase by $7.2 \%$ with the increase of $1 \%$ dependency ratio. There is a positive association between livelihood strategy choice and skill development training indicates that a $1 \%$ increase of the skill development training would lead to a $10.7 \%$ increases probability of adopting livelihood strategy Y 3 (crop plus fish farming). Total land holdings represent the total own cultivated land held by a farm household and may be taken as an indicator of wealth for a farm household. The results indicate that the total land area has negative and significant impacts on households involved in crop plus poultry farming. Therefore, a $1 \%$ increase in the own cultivated land is likely to decrease the probability of adopting the crop plus poultry farming as a livelihood strategy by $7.5 \%$. The marginal effects of household assets value exhibit very different behavior depending on the outcome category (Amare and Simane 2017). An increase in the household assets value is likely to increase the probability of adopting the livelihood strategy Y2 (crop plus livestock farming), whereas it is likely to decrease the probability of adopting the livelihood strategy Y5 (crop plus off-farm activities). The result of access to credit shows that keeping the effect of other variables constant, the likelihood of choosing crop plus offfarm activities is $8.8 \%$ lower than for farmers without credit facilities. There is a positive relationship between household's annual incomes and the likelihood of accessing crop plus poultry farming and crop plus off-farm activities indicating that a $1 \%$ increase of the annual income would likely increase the adoption of the crop plus poultry farming and crop plus off-farm activities by $6.10 \mathrm{e}-05 \%$ and $3.40 \mathrm{e}-05 \%$ respectively. Membership of any organization showed a positive and significant relationship with the adoption of the crop plus livestock farming indicating a unit increase of the membership facilities in an organization increases the probability of crop plus livestock farming by $7.7 \%$. Home to road distance is positively related to the crop plus livestock farming and crop plus poultry farming, and negatively related to the crop plus off-farm activities. It indicates a $1 \%$ increase of the home to road distance results in an increase of crop plus livestock farming and crop plus poultry farming by $11.9 \%$ and $10.4 \%$ respectively. Whereas a decrease of $18 \%$ in the probability of adopting crop plus off-farm activities with the increase of $1 \%$ home to road distance. Similarly, home to market distance has a positive association with the crop plus fish farming, crop plus off-farm activities, and a negative association with the crop plus livestock farming. Home to haor distance shows positive and significant evidence with the adoption of the crop plus off-farm activities indicating a $1 \%$ increase of the home to haor distance would lead to an increase of a $5.5 \%$ in the probability of choosing crop plus off-farm activities as a livelihood diversification strategy (Hoq et al. 2021b). Roadway communication during monsoon significantly and negatively influences the haor household in adopting livelihood diversification compared to its base category river way communication. The results indicate that a $1 \%$ increase in roadway communication decreases the probability of adopting crop plus fish farming by $14.5 \%$. On the contrary, riverway and both way (road and riverways) communication during dry season significantly and positively influence the haor household in adopting crop plus poultry farming and crop plus livestock farming respectively. It indicates that one unit increase in the riverway communication increases the probability of choosing crop plus poultry farming by $15.2 \%$ and 'increases the probability of choosing crop plus livestock farming by $7.9 \%$ as a livelihood strategy. Unexpectedly duration of waterlogged significantly and positively influences the crop plus livestock livelihood strategy which indicates one unit (month) increase in the duration of waterlogged is likely to increase the probability of crop plus livestock farming by $3.4 \%$ (Hoq et al. 2021b). Hence, it may be due to rearing livestock in household home yard which is physically observed during the data collection. Farmers living in different agro-ecological settings used different livelihood strategies as a measure of different adaptation strategies. Farming in medium high land agro-ecology significantly decreases the probability of crop plus livestock farming by $6.6 \%$ and significantly increases the probability of adopting crop plus fish farming by $8.3 \%$ compared with farming in low land agro-ecology. 
Table 6

Marginal effect after multinominal logistic regression (MNL) of livelihood strategy model

\begin{tabular}{|c|c|c|c|c|}
\hline Livelihood platform variable & $\begin{array}{l}Y_{2}=\text { Crop + Livestock } \\
\text { farming }\end{array}$ & $\begin{array}{l}Y_{3}=\text { Crop + Fish } \\
\text { farming }\end{array}$ & $\begin{array}{l}Y_{4}=\text { Crop + Poultry } \\
\text { farming }\end{array}$ & $\begin{array}{l}Y_{5}=\text { Crop + Off-farm } \\
\text { activities }\end{array}$ \\
\hline \multicolumn{5}{|l|}{ Human capital } \\
\hline \multirow[t]{2}{*}{ Gender of HH head } & \multirow[t]{2}{*}{$0.095(0.084)$} & 0.173 & 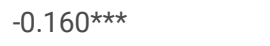 & -0.095 \\
\hline & & $(0.120)$ & $(0.060)$ & $(0.071)$ \\
\hline \multirow[t]{2}{*}{ Age of $\mathrm{HH}$ head } & 0.0004 & 0.003 & -0.0006 & 0.0004 \\
\hline & $(0.002)$ & $(0.002)$ & $(0.002)$ & $(0.002)$ \\
\hline \multirow[t]{2}{*}{ Education of $\mathrm{HH}$ head } & 0.002 & 0.002 & -0.0003 & $0.010 \star$ \\
\hline & $(0.004)$ & $(0.005)$ & $(0.006)$ & $(0.006)$ \\
\hline \multirow[t]{2}{*}{ Family size } & $0.022^{\star \star}$ & -0.006 & $-0.023^{\star}$ & 0.013 \\
\hline & $(0.009)$ & $(0.011)$ & $(0.013)$ & $(0.014)$ \\
\hline \multirow[t]{2}{*}{ Dependency ratio } & -0.003 & -0.053 & $0.072^{\star \star}$ & -0.006 \\
\hline & $(0.040)$ & $(0.044)$ & $(0.036)$ & $(0.043)$ \\
\hline \multirow[t]{2}{*}{ Agricultural training } & 0.027 & -0.014 & 0.008 & -0.048 \\
\hline & $(0.043)$ & $(0.053)$ & $(0.052)$ & $(0.058)$ \\
\hline \multirow[t]{2}{*}{ Skill development training } & -0.018 & $0.107 * \star$ & -0.053 & -0.082 \\
\hline & $(0.042)$ & $(0.050)$ & $(0.053)$ & $(0.062)$ \\
\hline \multicolumn{5}{|l|}{ Natural capital } \\
\hline \multirow[t]{2}{*}{ Total land holdings } & -0.025 & -0.027 & $-0.075^{\star \star \star}$ & -0.033 \\
\hline & $(0.018)$ & $(0.021)$ & $(0.025)$ & $(0.028)$ \\
\hline \multicolumn{5}{|l|}{ Physical capital } \\
\hline \multirow[t]{2}{*}{ Household assets value } & $4.62 \mathrm{e}-07 * \star \star$ & $7.99 \mathrm{e}-08$ & $4.05 e-09$ & $-3.47 e-07 \star \star$ \\
\hline & $(6.36 \mathrm{e}-08)$ & $(8.76 e-08)$ & $(1.08 \mathrm{e}-07)$ & $(1.61 e-07)$ \\
\hline \multicolumn{5}{|l|}{ Financial capital } \\
\hline \multirow[t]{2}{*}{ Access to credit } & 0.025 & -0.020 & -0.054 & $-0.088 \star \star$ \\
\hline & $(0.037)$ & $(0.044)$ & $(0.042)$ & $(0.045)$ \\
\hline \multirow[t]{2}{*}{ Annual income } & $-9.33 e-08$ & $2.01 e-07$ & $4.98 \mathrm{e}-07 * \star \star$ & $3.30 \mathrm{e}-07 *$ \\
\hline & $(1.15 \mathrm{e}-07)$ & $(1.40 \mathrm{e}-07)$ & $(1.37 e-07)$ & $(1.84 \mathrm{e}-07)$ \\
\hline \multirow[t]{2}{*}{ Annual expenditure } & $3.08 \mathrm{e}-07$ & $2.94 \mathrm{e}-07$ & $1.62 \mathrm{e}-07$ & $-4.33 e-07$ \\
\hline & $(2.12 \mathrm{e}-07)$ & $(2.72 \mathrm{e}-07)$ & $(2.97 e-07)$ & $(3.98 e-07)$ \\
\hline \multicolumn{5}{|l|}{ Social capital } \\
\hline \multirow{2}{*}{$\begin{array}{l}\text { Membership of any } \\
\text { organization }\end{array}$} & $0.077^{\star *}$ & 0.025 & -0.019 & 0.041 \\
\hline & $(0.038)$ & $(0.045)$ & $(0.049)$ & $(0.055)$ \\
\hline \multicolumn{5}{|l|}{ Infrastructures } \\
\hline \multirow[t]{2}{*}{ Home to road distance } & $0.119 * \star$ & 0.003 & $0.104^{\star}$ & $-0.180 * \star$ \\
\hline & $(0.056)$ & $(0.061)$ & $(0.063)$ & $(0.080)$ \\
\hline \multirow[t]{2}{*}{ Home to market distance } & $-0.156^{\star \star \star}$ & $0.093^{\star \star \star}$ & -0.005 & $0.060 * *$ \\
\hline & $(0.050)$ & $(0.028)$ & $(0.041)$ & $(0.029)$ \\
\hline \multirow[t]{2}{*}{ Home to haor distance } & 0.031 & -0.042 & 0.002 & $0.055^{\star}$ \\
\hline & $(0.028)$ & $(0.033)$ & $(0.031)$ & $(0.032)$ \\
\hline
\end{tabular}

(Note: ${ }^{* \star}, * \star * *$ indicates the $1 \%, 5 \%$ and $10 \%$ level of significance, figures in the parentheses indicate standard error) 


\begin{tabular}{|c|c|c|c|c|}
\hline Livelihood platform variable & $\begin{array}{l}Y_{2}=\text { Crop + Livestock } \\
\text { farming }\end{array}$ & $\begin{array}{l}Y_{3}=\text { Crop + Fish } \\
\text { farming }\end{array}$ & $\begin{array}{l}Y_{4}=\text { Crop + Poultry } \\
\text { farming }\end{array}$ & $\begin{array}{l}Y_{5}=\text { Crop + Off-farm } \\
\text { activities }\end{array}$ \\
\hline $\begin{array}{l}\text { Communication during } \\
\text { monsoon }\end{array}$ & \multicolumn{4}{|c|}{ River way is reference category } \\
\hline \multirow[t]{2}{*}{ Road way } & -0.172 & $-0.145^{\star \star \star}$ & 0.420 & -0.141 \\
\hline & $(0.254)$ & $(0.020)$ & $(0.390)$ & $(0.098)$ \\
\hline \multirow[t]{2}{*}{ Both way } & -0.002 & 0.110 & -0.088 & -0.058 \\
\hline & $(0.072)$ & $(0.102)$ & $(0.056)$ & $(0.075)$ \\
\hline $\begin{array}{l}\text { Communication during dry } \\
\text { season }\end{array}$ & \multicolumn{4}{|c|}{ Road way is reference category } \\
\hline \multirow[t]{2}{*}{ River way } & 0.079 & 0.028 & $0.152^{\star \star}$ & -0.083 \\
\hline & $(0.057)$ & $(0.064)$ & $(0.074)$ & $(0.057)$ \\
\hline \multirow[t]{2}{*}{ Both way } & $0.079 *$ & 0.015 & -0.011 & 0.043 \\
\hline & $(0.045)$ & $(0.048)$ & $(0.043)$ & $(0.055)$ \\
\hline \multicolumn{5}{|l|}{ Geographical factors } \\
\hline \multirow[t]{2}{*}{ Duration of waterlogged } & $0.034^{*}$ & -0.005 & 0.022 & -0.016 \\
\hline & $(0.019)$ & $(0.017)$ & $(0.019)$ & $(0.016)$ \\
\hline Agro-ecology & \multicolumn{4}{|c|}{ Low land is reference category } \\
\hline \multirow[t]{2}{*}{ Medium high land } & $-0.066^{*}$ & $0.083^{\star \star}$ & -0.019 & -0.029 \\
\hline & $(0.037)$ & $(0.042)$ & $(0.041)$ & $(0.045)$ \\
\hline \multirow[t]{2}{*}{ High land } & $0.136^{\star}$ & 0.074 & 0.022 & 0.066 \\
\hline & $(0.080)$ & $(0.074)$ & $(0.087)$ & $(0.094)$ \\
\hline
\end{tabular}

\section{Discussion}

The study categorizes a household's entire livelihood activities into five livelihood strategies groups pursued in the study areas of the wetland haor ecosystem of Bangladesh. Those strategies mainly consist of various agricultural production practices and non-farm activities (e.g., petty business, wage labor, migratory work, etc.), which are consistent with the findings of Jiao et al. (2017) in rural Cambodia. This diverse set of livelihood approaches and income composition of each livelihood strategy suggest that rural household mostly involves in multiple income-earning activities, which are essential for survival and for reducing risk and uncertainty in the production process of the unfavorable ecosystem in rural areas (Liu and Lan 2015; Jiao et al. 2017; Ellis 1998 2000). Income from the crop sector contributes the largest share to household total income, and income from rice production is still indeed the primary source of farm income for haor households, especially for the subsistence farmer. These findings are closely related to the findings of Rigg et al. (2016) and Gautam and Andersen (2016) in the case of East and Southeast Asia's smallholders. Previous studies reported that about $80 \%$ of haor areas are covered by boro rice cultivation and another $10 \%$ is covered by transplanted Aman rice (Huda 2004; Khan et al. 2012; Hoq et al. 2021a). The results revealed that most of the haor households engaged in agriculture-based livelihood, especially in rice crop farming (only crop farming livelihood strategy), and they earn low and sometimes negative returns from crop farming but cannot stop due to financial barriers and finding no alternative way; these findings are supported by Alamgir et al. (2020). The most lucrative livelihood strategy is found in pursuing crop plus livestock farming that generated higher income from crop and livestock sales. This result agrees with Khatiwada et al.'s (2017) findings for rural household livelihood strategies in central Nepal. The study also identified some other profitable livelihood options such as crop plus fish farming, crop plus poultry farming, and crop plus off-farm activities in haor areas of Bangladesh which also supported by some previous studies (Islam 2011; Islam et al. 2012; Parvin and Akteruzzaman 2013; Sunny et al. 2020; Uddin et al. 2019). These livelihood strategies require a significant amount of capital investment to start up that is why the majority of them are unable to participate; such findings are in line with Gautam and Andersen's findings (2016). The asset-poor haor households are unable to overcome the entry barriers to high return sectors and are confined to low return sectors that cannot contribute significantly to their well-being (Singh et al. 2018). Some innovative farmers diverse their livelihood activities into livestock, fisheries, and poultry farming and off-farm activities along with crop farming to combat natural disasters in their production process. Age and education of the household head and dependency ratio are most influencing human capital in adopting the higher returning livelihood strategies (Xu et al. 2019) which has consistent with the present study. The positive and significant coefficient of the age variable indicates that the elderly have enough capacity to accumulate assets to enable them to invest and diversify their activities into crop plus fish farming, which is consistent with the finding of Rahut et al. (2017) for diversifying rural livelihood into non-farm sectors in Bhutan. Similarly, the positive and significant coefficient of the $\mathrm{HH}$ head education reflects that higher education is likely to develop more skilled and capable entrepreneurs that influence them to adopt crop plus off-farm activities; these findings are also supported by the previous studies (Khatun and Roy 2012; Khatiwada et al. 2017; Rahut et al. 2017). The family size determinant was found to be positively related to crop plus livestock farming, which is contrary to the results of Khatun and Roy (2012) and Gebru et al. (2018). One probable explanation is that when the number of members of a household increased, the likelihood of them becoming 
more involved in livestock farming keeps growing as well. The results of the natural capital indicated that there is a negative and significant relationship between total landholding and the choice of adopting all higher returning livelihood strategies. The argument is that low return from subsistence farming alone cannot sustain the smallholder's rural livelihood which compels them to generate higher income from limited farm size through diversifying their activities into more than only crop farming (Khatiwada et al., 2017). Therefore, the haor households with large landholdings do not have a surplus labor force that can be able to diversify (Rahut et al. 2017). Physical capital found a positive and significant relationship between household asset value (farm and non-farm) and the two most profitable livelihood diversification strategies: crop plus livestock farming and crop plus fish farming. It is true that households with a high initial livelihood asset indeed have greater freedom of choosing and diversifying their livelihood into higher-returning crop plus livestock and crop plus fish farming and benefited most. These findings are consistent with the findings of Adepoju and Obayelu (2013), Loison (2015), and Gebru et al. (2018). The support of financial capital is very important to start up a new livelihood strategy (Khatiwada et al. 2017; Xu et al. 2019).

Unfortunately, the credit facility is negatively related to adopting all livelihood diversification strategies and significantly influences the crop plus poultry and crop plus off-farm livelihood strategies. The result, however, contradicts the findings of Gebru et al. (2018) and Davies (2004). The possible explanation could be that the haor household may not be able to utilize the credit properly in the livelihood activities. Sunny et al. (2020) also found an easy source of informal credit with unfavorable interest, terms, and conditions for the haor household, which aggravate their poverty level. Household annual income from the respective livelihood strategies positively and significantly influences all livelihood diversification strategies. Analysis reveals a positive and significant relationship between membership of any organization (social capital) and livelihood strategies Y2 (crop plus livestock farming) and Y3 (crop plus fish farming), which is consistent with the findings of Khatun and Roy (2012) and Khatiwada et al. (2017). Rural infrastructure, particularly household home to road, market, and haor distance were found significant determinants influencing livelihood strategy choice. The results indicate an increase in the distance from home to the road increases the probability of adopting the crop plus livestock farming and crop plus poultry farming. It could be due to the availability of land and grassland which is favorable for crop production and livestock grazing as well as poultry farming (Rabby et al. 2013). Similarly, greater distance from home to haor enables haor household to adopt the higher retuning livelihood strategy, especially significantly influence in adopting the crop plus off-farm activities. On the other hand, proximity to market place is favorable for crop plus livestock farming because households being closer to market place can easily sell their livestock products at a higher price (Khatiwada et al. 2017). Riverway and both-way (river and roadways) communications are significantly and positively related to livelihood strategy Y2 (crop plus livestock farming) since the river and both-way communication promote livestock rearing and grazing. The livelihood strategy Y3 (crop plus fish farming) is positively and significantly influenced by riverway communication during the dry season, which may be due to their ability to connect with the marketplace for fish marketing with low transportation costs (Sunny et al. 2020). In line with our expectation, riverway communication is to be positively and significantly influence the livelihood strategy Y4 (crop plus poultry farming). Riverway communication is one of the most influential factors for poultry farming, particularly duck rearing, in the rural haor areas of Bangladesh (Islam et al. 2012). Geographical and ecological characteristics such as waterlogged duration and agro-ecology have a positive and significant impact on the choice of a livelihood strategy (Rahman and Hickey 2020). Opposite of our expectation, the livelihood strategy Y2 (crop plus livestock farming) is positively related to the duration of waterlogging (months), possibly due to providing more effort during monsoon as it is the lean season for crop farming. As expected, the duration of waterlogging was found to be one of the important determinants of adopting a livelihood strategy Y4 (crop plus poultry farming), because duck rearing is required of persistent water for a long time (Islam et al. 2012; Khanum and Mahadi 2015). According to the study, highland households are more likely than lowland households to adopt strategic livelihood diversification in the wetland ecosystem (Islam et al. 2011).

\section{Conclusion And Recommendations}

The study looked at the various livelihood strategies practiced by haor households as well as the major determinants that influence the choice of those livelihood diversification strategies in the study areas. Flash floods, floods, droughts, riverbank erosion, and embankment breach are the extreme natureinduced disasters that caused increasing harm to the poor in crop production and livelihood diversification was the indigenous strategy to adapt to climateinduced vulnerabilities. Crop farming has been identified as the primary economic activity and source of income for many households, even though it is unprofitable. In addition to crop farming, which is commonly done by rural haorhouseholds, the study discovered four viable livelihood diversification alternatives. Rice is the primary crop for all types of livelihood strategies which contributes alone a range of $43-91 \%$ of the total household income of all livelihood strategy groups. The crop plus livestock strategy group (Y2) has gained the highest annual average income followed by crop plus fish (Y3), crop plus poultry (Y4), crop plus off-farm activities (Y5), and only crop farming (Y1). Therefore, crop production supplemented by livestock farming or fish farming or poultry farming (duck rearing), or off-farm activities could be an important means of subsistence. Multinomial logistics regression results showed that household's head age and education, dependency ratio, total land holdings, household assets value, access to credit, annual income, membership of any organization, home to road, market, and haor distance, river, and both way communication during the dry season, duration of waterlogged, and agro-ecology are the major determinants that significantly influence the choice of higher returning livelihood strategies. Furthermore, marginal effect analysis revealed that household's head gender and education, family size, dependency ratio, skill development training, land holdings, household assets value, access to credit, annual income, membership of any organization, home to road, market, and haor distances, roadway communication during monsoon, river and both way communication during the dry season, duration of waterlogged, and medium high land type agroecology are the significant determinants of choosing better-paying livelihood strategies which measure the percentage change in probability of a particular choice being made to a unit change of a particular variable. Therefore, it is recommended that such significant determining factors of livelihood strategy choice can be promoted through policy interventions that have a significant impact on sustainable livelihood. In addition, the government should put in place effective policies to make livestock, fisheries, and poultry easier for the haor community. Community-owned grazing land, such as community grasslands, is a better choice for safeguarding livestock farmers in the haor areas. Fishing is a seasonal business that can only be undertaken for a few months of the year, leaving people unemployed for the rest of the year and allowing them to diversify their activities. The haor basin, on the other side, has enormous potential for commercial duck farming. The availability of natural duck feeding sources and a tradition of duck farming in the haor region are the factors that may be prompted for developing duck farming in this area. However, these sustainable strategies require enormous capital investment, which is 
why most of them cannot participate in these livelihood diversification strategies. For ensuring participation in these livelihood opportunities governments, NGOs, and other development organizations should initiate different policies and programs such as credit facilities for assets accumulations, skill development training, and training for improved fisheries, livestock and poultry farming, etc.

\section{Declarations}

\section{Acknowledgements}

The authors would like to express their appreciation to the Bangladesh government and the Bangladesh Agricultural Research Council (BARC) for funding the first author's PhD research through the NATP-2 (National Agricultural Technology Program-Phase II) Project. The authors would like to express their gratitude to PIU (Project Implementation Unit), NATP-Phase-II, BARC for funding the first author's PhD fellowship program. All contributors who provided critical feedback, read and approved the final manuscript are acknowledged. The manuscript was based in part of the first author's doctoral dissertation, which was submitted to Bangladesh Agricultural University-2202.

Author contributions: The authors' individual contributions to the paper are as follows: Mohammad Shamsul Hoq: Conceptualization, methodology, data analysis, software, writing, reviewing and editing original draft and finalization. Md. Taj Uddin: Conceptualization, writing, reviewing, editing, and validation. Shankar Kumar Raha: Writing, reviewing, editing, and validation and supervision. Mohammad Ismail Hossain: Conceptualization, Writing, reviewing, editing, and validation and supervision. All authors have approved the manuscript.

Funding: This work was supported by the National Agricultural Technology Project (NATP), Bangladesh Agricultural Research council (BARC), Dhaka.

Availability of data and materials: The datasets used and/or analyzed during the current study are available from the corresponding author on reasonable request.

Competing Interest: The authors declare that they have no known competing financial interests or personal relationships that may have affected the research presented in this paper.

Human and animal rights: This research does not involve human or animal participants.

\section{References}

Adnan KMM, Ying L, Sarker SA, Yu, MM, Tama RAZ (2021) Simultaneous adoption of diversification and agricultural credit to manage catastrophic risk for maize production in Bangladesh. Environ Sci Pollut Res. https://doi.org/10.1007/s11356-021-14737-1

Abera A, Yirgu T, Uncha A (2021) Determinants of rural livelihood diversification strategies among Chewaka resettlers' communities of southwestern Ethiopia. Agric \& Food Secur 10, 30. https://doi.org/10.1186/s40066-021-00305-w

Ahmad D, Afzal M (2020) Flood hazards and factors influencing house-hold flood perception and mitigation strategies in Pakistan. Environ Sci Pollut Res 27(13):15375-15387. https://doi.org/10.1007/s11356-020-08057-z

Akter M, Ahmed JU, Fatema K, Datta T, Akter K (2020) Factors affecting extent of haor livelihood diversification in Sunamganj district, Bangladesh. AJAEES 38(10):43-51

Alamgir MS, Furuya J, Kobayashi S, Mostafiz RB, Ahmed MR (2020) Farm income, inequality, and poverty among farm families of a flood-prone area in Bangladesh: climate change vulnerability assessment. Geo Journal. https://doi.org/10.1007/s10708-020-10231-2

Ali S, Kashem MA, Aziz MA (2019) Agro-economic performance of boro rice cultivation at farmers' level of haor area in Bangladesh. Int. J. Agric. Environ. Food Sci. 3(2):78-82. DOI: https://dx.doi.org/10.31015/jaefs.2019.2.5

Amare A, Simane B (2017) Determinants of smallholder farmers' decision to adopt adaptation options to climate change and variability in the Muger Sub basin of the Upper Blue Nile basin of Ethiopia. Agric. \& Food Security 6: 64. https://doi.org/10.1186/s40066-017-0144-2.

Alam MSU, Ahmed JU, Mannaf M, Fatema K, Mozahid MN (2017) Farm and non-farm income diversification in selected Areas of Sunamganj district of Bangladesh. AJAEES 21(2):1-9

Abid, M., Scheffra, J., Schneider, U. A., Ashfaq, M., 2015. Farmers' perceptions of and adaptation strategies to climate change and their determinants: The case of Punjab province, Pakistan. Earth System Dynamics 6(1), 225-243. DOI:10.5194/esd-6-225-2015

Agarwala M, Atkinson G, Fry BP, Homewood K, Mourato S, Rowcliffe J M, et al. (2014) Assessing the relationship between human well-being and ecosystem services: A review of frameworks. Conservation and society 12: 437

Adepoju AO, Obayelu OA (2013) Livelihood diversification and welfare of rural households in Ondo State, Nigeria. J Dev Agric Econ. 5(12): 482-489

Alam MS, Quayum MA, Islam MA (2010) Crop production in the haor areas of Bangladesh: Insights from farm level survey. The Agriculturists 8(2):88-97 
Bhowmik J, Irfanullah HM, Selim SA (2021) Empirical evidence from Bangladesh of assessing climate hazard-related loss and damage and state of adaptive capacity to address them. Clim. Risk Manage. 31,100273. https://doi.org/10.1016/j.crm.2021.100273

Blackmore I, Rivera C, Waters WF, lannotti L, Lesorogol C (2021) The impact of seasonality and climate variability on livelihood security in the Ecuadorian Andes. Clim. Risk Manage. 32:100279. https://doi.org/10.1016/j.crm.2021.100279

BBS (2019) Statistical year book Bangladesh, Bangladesh Bureau of Statistics, Government of the People's Republic of Bangladesh

Basak SR, Basak AC, Rahman MA (2015) Impacts of floods on forest trees and their coping strategies in Bangladesh. Weather and Climate Extremes 7: 4348. https://doi.org/10.1016/j.wace.2014.12.002

BHWDB (2012) Master plan of Haor area: volume I summary report. Ministry of Water Resources, Government of Bangladesh, Dhaka

Babulo B, Muys B, Nega F, Tollens E, Nyssen J, Deckers J, Mathijs E (2008) Household livelihood strategies and forest dependence in the highlands of Tigray, Northern Ethiopia. Agric. Syst. 98:147-155

Brouwer R, Akter S, Brander L, Haque E (2007) Socioeconomic vulnerability and adaptation to environmental risk: A Case study of climate change and flooding in Bangladesh. Risk Analysis 27(2):313-326. DOI: 10.1111/j.1539-6924.2007.00884.x

Brown DR, Stephens EC, Ouma JO, Murithi FM, Barrett CB (2006) Livelihood strategies in the rural Kenyan highlands; Cornell University: Ithaca, NY, USA

Bowen HP, Wiersema MF (2004) Modeling limited dependent variables: Guidelines for researchers of strategic management. In D. J. Ketchen \& D. Bergh (Eds.), Research methodology in strategy and management (Vol. 1, pp. 87-134). Oxford, UK: JAl/Elsevier Press

Banglapedia (2003) Climate and floods, National Encyclopedia of Bangladesh, The Revised Second Edition (2012). Asiatic Society of Bangladesh. http://en.banglapedia.org/index.php/Bangladesh

Barrett CB, Reardon T, Webb P (2001) Non-farm income diversification and household livelihood strategies in rural Africa: concepts, dynamics, and policy implications. Food Policy 26(4):315-31

CAN (2017) Floods in Northeast (Haor) areas of Bangladesh, April-May 2017, HCTT Coordinated Needs Assessment (CAN), Bangladesh

CIRDAP (2016) Climate Change Vulnerability: Cases from CIRDAP Member Countries. Centre on Integrated Rural Development for Asia and the Pacific, Dhaka, Bangladesh

Carney, D. 1998. Sustainable rural livelihoods: What contribution can we make? In proceedings of the department for international development's natural resources advisers' conference, London, UK, 10-14 July 1998; Department for international development (DFID): London, UK

Chambers R, Conway R (1992) Sustainable rural livelihood: practical concept for the 21st century, Discussion paper, IDS No. 296, Institute of Development Studies, Library Road, Brighton, UK

Donatti Cl, Harvey CA, Martinez-Rodriguez MR, Vignola R, Rodriguez CM (2019) Vulnerability of smallholder farmers to climate change in Central America and Mexico: current knowledge and research gaps, Climate and Development 11(3): 264-286. DOI: 10.1080/17565529.2018.1442796

Dewan H (2015) Societal impacts and vulnerability to floods in Bangladesh and Nepal. Weather Climate Extremes 7: 36-42

DoF (2015) National Fish Week 2015 Compendium (in Bangla), Department of Fisheries. Ministry of Fisheries and Livestock, Bangladesh.148p

Davis B, Winters P, Carletto G, Covarrubias K, Quiñones EJ, Zezza A, Stamoulis K, Azzarri C, DiGiuseppe S (2010) A cross-country comparison of rural income generating activities. World Dev. 38: 48-63.

Deressa TT, Hassan, RM, Ringler C, Alemu T, Yesuf M (2009) Determinants of farmers' choice of adaptation methods to climate change in the Nile Basin of Ethiopia. Global Environmental Change 19(2): 248-255

Davis J (2004) The Rural Non-farm Economy, Livelihoods and their Diversification: Issues and Options. Natural Resource Institute, Chatham, UK

Elahi E, Zhang L, Abid M, Altangerel O, Bakhsh K, Uyanga B, Ahmed Ul, Xinru H, (2015) Impact of balance use of fertilizers on wheat efficiency in cotton wheat cropping system of Pakistan. Int. J. Agric. Innov. Res. 3:1470-1474

Ellis F (2000) The determinants of rural livelihood diversification in developing countries. Journal of Agricultural Economics 51(2):289-302

Ellis F (1998) Household strategies and rural livelihood diversification. J. Dev. Stud. 35:1-38.

Ferdushi KF, Ismail MT, Kamil AA (2019) Perceptions, knowledge and adaptation about climate change: A study on farmers of haor areas after a flash flood in Bangladesh. Climate 7(7):85. https://doi.org/10.3390/cli7070085 
Gebru GW, Ichoku HE, Phil-Eze PO (2018) Determinants of livelihood diversification strategies in Eastern Tigray Region of Ethiopia. Agric \& Food Secur 7:62. https://doi.org/10.1186/s40066-018-0214-0

Gautam y, Andersen P (2016) Rural livelihood diversification and household well-being: Insights from Humla, Nepal. Journal of Rural Studies $44: 239-249$

Green HW (2003) Econometric analysis. $4^{\text {th }}$ ed. New York: Macmillan Publishing Company

Hoq MS, Raha SK, Hossain MI (2021a) Livelihood vulnerability to flood hazard: Understanding from the flood-prone haor ecosystem of Bangladesh. Environmental Management 67:532-552. https://doi.org/10.1007/s00267-021-01441-6

Hoq MS, Uddin MT, Raha SK, Hossain, MI (2021b) Welfare impact of market participation: the case of rice farmers from wetland ecosystem in Bangladesh, Environmental Challenges 5:100292. doi: https://doi.org/10.1016/j.envc.2021.100292

Hoque SM, Quinn C, Sallu S (2018) Differential livelihood adaptation to social-ecological change in coastal Bangladesh. Reg Environ Change 18:451-463. DOI 10.1007/s10113-017-1213-6

Hossain MA (2013) Socio-economic analysis of the Haor-A case study of the Hakaluki haor. MEcon thesis. Dhaka school of economics, University of Dhaka, Dhaka, Bangladesh.

Huque KS, Saleque MA, Khatun R (2011) Commercial poultry production in Bangladesh. Published in WPSA_BB souvenir, World Poultry Science Association-Bangladesh Branch (WAPSA-BB), Bangladesh

Huda MK (2004) Experience with modern and hybrid rice varieties in Haor ecosystem: Emerging technologies for sustainable rice production. Twentieth National Workshop on Rice Research and Extension in Bangladesh. Bangladesh Rice Research Institute. Gazipur-1701, 19- 21 April 2004

Hausman J, McFadden D (1984) Specification tests for the multinomial logit model. Econometrica 52(5):1219-1240

Islam MM, Islam N, Sunny AR, Jentoft S, Ullah MH, Sharifuzzaman SM (2016a) Fishers' perceptions of the performance of hilsa shad (Tenualo sailisha) sanctuaries in Bangladesh. Ocean \& Coastal Management 130:309-316

Islam MA, Siddique MNH, Karim, AAME (2016b) Exploring the boat accessibility to school students in the remote haor village during monsoon. Participatory action research: Reflection and learning, Integrated Development Programme (IDP), BRAC, Bangladesh

Islam MA, Siddique MNH, Karim AAME (2016c) How the poultry livestock extension workers applied their lessons to their lives Participatory action research: Reflection and learning, Integrated Development Programme (IDP), BRAC, Bangladesh

Islam MM, Bhuiyan MNK, Harun MY (2012) Development of value chain: An effective way of profitable duck farming in haor areas of Bangladesh. INFPD good practices of family poultry production Note No 04, Bangladesh

Islam MR, Hoque MN, Galib SM, Rahman MA (2013) Livelihood of the fishermen in Monirampur upazila of Jessore district, Bangladesh. J. Fish. 1(1):37-41 Islam S, Uddin MT, Akteruzzaman M, Rahman M, Haque MA (2011) Profitability of alternate farming systems in Dingapota haor area of Netrokona district. Progress Agric 22(1\&2):223-239.

Jiao X, Pouliot M, Walelign SZ (2017) Livelihood strategies and dynamics in rural Cambodia. World Development 97(C): 266-

278. http://dx.doi.org/10.1016/j.worlddev.2017.04.019

Kabir et al. (2020) Harvesting of boro paddy in Haor areas of Bangladesh: Interplay of local and migrant labour, mechanized harvesters and Covid-19 vigilance in 2020, 40 pages. BRRI, Gazipur 1701, Bangladesh

Kamal ASMM, Shamsudduha M, Ahmed B, Hassan SMK, Islam MS, Kelman I, Fordham M (2018) Resilience to flash floods in wetland communities of northeastern Bangladesh. International Journal of Disaster Risk Reduction 31:478-488

Kamruzzaman M, Shaw R (2018) Flood and sustainable agriculture in the haor basin of Bangladesh: A review paper. Universal Journal of Agricultural Research 6 (1):40-49. DOI: 10.13189/ujar.2018.060106

Khatiwada SP, Deng W, Paudel P, Khatiwada JR, Zhang J, Su Y (2017) Household livelihood strategies and implication for poverty reduction in rural areas of central Nepal. Sustainability 9:612. doi:10.3390/su9040612

Khanum R, Mahadi MSA (2015) Economic empowerment of haor women through duck farming in Bangladesh. The Agriculturists 13(1):18-25

Khan MNH, Mia MY, Hossain MR (2012) Impacts of flood on crop production in haor areas of two upazillas in Kishoregonj. J Environ Sci Nat Resour 5(1):193-198

Khan MI, Islam MA (2005) Poverty status of a critical wetland area. Hakaluki Haor: A IUCN report. The World Conservation Union, Bangladesh Country Office, Bangladesh

Page $21 / 25$ 
Kothari CR (2004) Research methodology: methods and techniques. New Delhi: New Age International Publishers

Liu Z, Lan J (2015). The sloping land conversion program in China: Effect on the livelihood diversification of rural households. World Development 70:147161

Loison SA (2015) Rural livelihood diversification in Sub-Saharan Africa: A Literature Review. J Dev Stud. 51(9):1125-38. DOI:10.1080/00220388.2015.1046445

Pagnani T, Gotor E, Caracciolo F (2020) Adaptive strategies enhance smallholders' livelihood resilience in Bihar, India. Food Sec. 13:419-437. https://doi.org/10.1007/s12571-020-01110-2

Parvin, M. T., Akteruzzaman, M., 2012. Factors affecting farm and non-farm income of haor inhabitants of Bangladesh. Progress. Agric. 23(1 \& 2):143 150

Pelling M (1999) The political ecology of flood hazard in urban Guyana. Geoforum 30:249-261

Rahman HMT, Hickey GM (2020) An analytical framework for assessing context-specific rural livelihood vulnerability. Sustainability $12: 5654$. doi:10.3390/su12145654

Roy A, Basu S (2020) Determinants of livelihood diversification under environmental change in coastal community of Bangladesh. Asia-Pacific Journal of Rural Development 30(1-2):7-26. Doi:10.1177/1018529120946159

Rahman HMT, Mia ME, Ford JD, Robinson BE, Hickey GM (2018a) Livelihood exposure to climatic stresses in the north-eastern floodplains of Bangladesh. Land Use Policy 79:199-214

Rahman HMT, Ford JD, Robinson BE, Hickey GM (2018b) How do capital asset interactions affect livelihood sensitivity to climatic stresses? Insights from the northeastern floodplains of Bangladesh. Ecol Econ 150:165-176

Rahman H MT, Miah ME, Ford JD, Robinson BE, Hickey GM (2018c) Livelihood exposure to climatic stresses in the northeastern flood plains of Bangladesh. Land Use Policy 79:199-214

Rahut DB, Mottaleb KA, Alib A (2017) Rural livelihood diversification strategies and household welfare in Bhutan. The European Journal of Development Research 30:718-748. doi:10.1057/s41287-017-0120-5

Rigg J, Salamanca A, Thompson, EC (2016) The puzzle of East and Southeast Asia's persistent smallholder. Journal of Rural Studies 43:118-133

Rahut DB, Ali A, Kassie M, Marenya PP, Basnet C (2014) Rural livelihood diversification strategies in Nepal. Poverty \& Public Policy 6:3

Rabby, T G., Fredericks, LJ, Alam GM (2013) Livestock husbandry strategy in alleviating poverty in the haor area of Bangladesh. Asian Journal of Animal and Veterinary Advances 8:41-52. doi: 10.3923/ajava.2013.41.52

Rana MP, Chowdhury MSH, Sohel MSI, Akhter S, Koike M (2009) Status and socio-economic significance of wetland in the tropics: a study from Bangladesh. iForest 2:172-177

Salam R, Ghose B, Shill BK et al. (2021) Perceived and actual risks of drought: household and expert views from the lower Teesta River Basin of northern Bangladesh. Nat Hazards 108:2569-2587. https://doi.org/10.1007/s11069-021-04789-4

Sunny AR, Masum KM, Islam N, Rahman M, Rahman A, Islam J et al. (2020) Analyzing Livelihood Sustainability of Climate Vulnerable Fishers: Insight from Bangladesh. J Aquac Res Development 11:6. doi: 10.35248/2155-9546.19.10.593

Sunny AR (2017) A review on the effect of global climate change on seaweed and seagrass. International Journal of Fisheries and Aquatic Studies 5:19-22

Sheuli SA (2017) Haor needs a dedicated early flash flood warning system. The independent, 27 May, 2017

Sunny AR (2017) A review on the effect of global climate change on seaweed and seagrass. International Journal of Fisheries and Aquatic Studies 5:19-22

Sarker MAR, Alam K, Gow J (2014) Assessing the effects of climate change on rice yields: An econometric investigation using Bangladeshi panel data, economic analysis and policy. 44(4):405-416. https://doi.org/ 10.1016/j.eap.2014.11.004

Soltani A, Angelsen A, Eid T, Naieni MSN, Shamekhi T (2012) Poverty, sustainability, and household livelihood strategies in Zagros. Iran. Ecol. Econ.79:6070

Sharma PK (2010) Scenario of haor vulnerabilities and other obstacles for sustainable livelihood development in Nikli upazila. Journal of Bangladesh Agricultural University 8(2):283-290. https://doi.org/10.3329/jbau.v8i2.7939

Trina BD, Roy NC, Das SK, Ferdausi HJ (2015) Socioeconomic Status of Fishers' Community at Dekhar Haor in Sunamganj District of Bangladesh. J. Sylhet Agril. Univ. 2(2):239-246

Page 22/25 
Toufique KA, Islam A (2014) Assessing risks from climate variability and change for disaster-prone zones in Bangladesh. International Journal of Disaster Risk Reduction 10:236-249

Tesfaye Y, Roos A, Campbell BM, Bohlin F (2011) Livelihood strategies and the role of forest income in participatory-managed forests of Dodola area in the bale highlands, southern Ethiopia. For. Policy Econ. 3:258-265.

Uddin MS, Haque E, Khan MN, Doberstein B, Cox RS (2021) "Disasters threaten livelihoods, and people cope, adapt and make transformational changes": Community resilience and livelihoods reconstruction in coastal communities of Bangladesh. International Journal of Disaster Risk Reduction 63:102444

Uddin MT, Hossain N, Dhar AR (2019) Business prospects and challenges in haorareas of Bangladesh, Journal of Bangladesh Agricultural University 17(1):65-72

Uddin MT, Dhar AR, Hossain N (2018) A socioeconomic study on farming practices and livelihood status of haor farmers in kishoregonj District: Natural calamities perspective. Bangladesh Journal of Extension Education 30(1):27-42

Wheeler R, Lobley M (2021) Managing extreme weather and climate change in UK agriculture: Impacts, attitudes and action among farmers and stakeholders. Clim. Risk Manage. 32:100313. https://doi.org/10.1016/j.crm.2021.100313

Wulff JN (2014) Interpreting results from the multinomial logit model: demonstrated by foreign market entry. Organ Res Meth. https://doi.org/10. $1177 / 1094428114560024$

Wooldridge M (2010) Econometrics analysis of cross section and panel data. MIT press

Woldenhanna T, Oskam A (2001) Income diversification and entry barriers: evidence from the Tigray region of northern Ethiopia. Food Policy 26 (4):351-365

Xu D, Deng X, Guo S, Liu S (2019) Sensitivity of livelihood strategy to livelihood capital: An empirical investigation using nationally representative survey data from rural China. Soc. Indic. Res. 144:113-131. https://doi.org/10.1007/s11205-018-2037-6

Zhou W, Guo S, Deng X. et al.(2021) Livelihood resilience and strategies of rural residents of arthquake-threatened areas in Sichuan Province, China. Nat Hazards 106: 255-275. https://doi.org/10.1007/s11069-020-04460-4

\section{Figures}



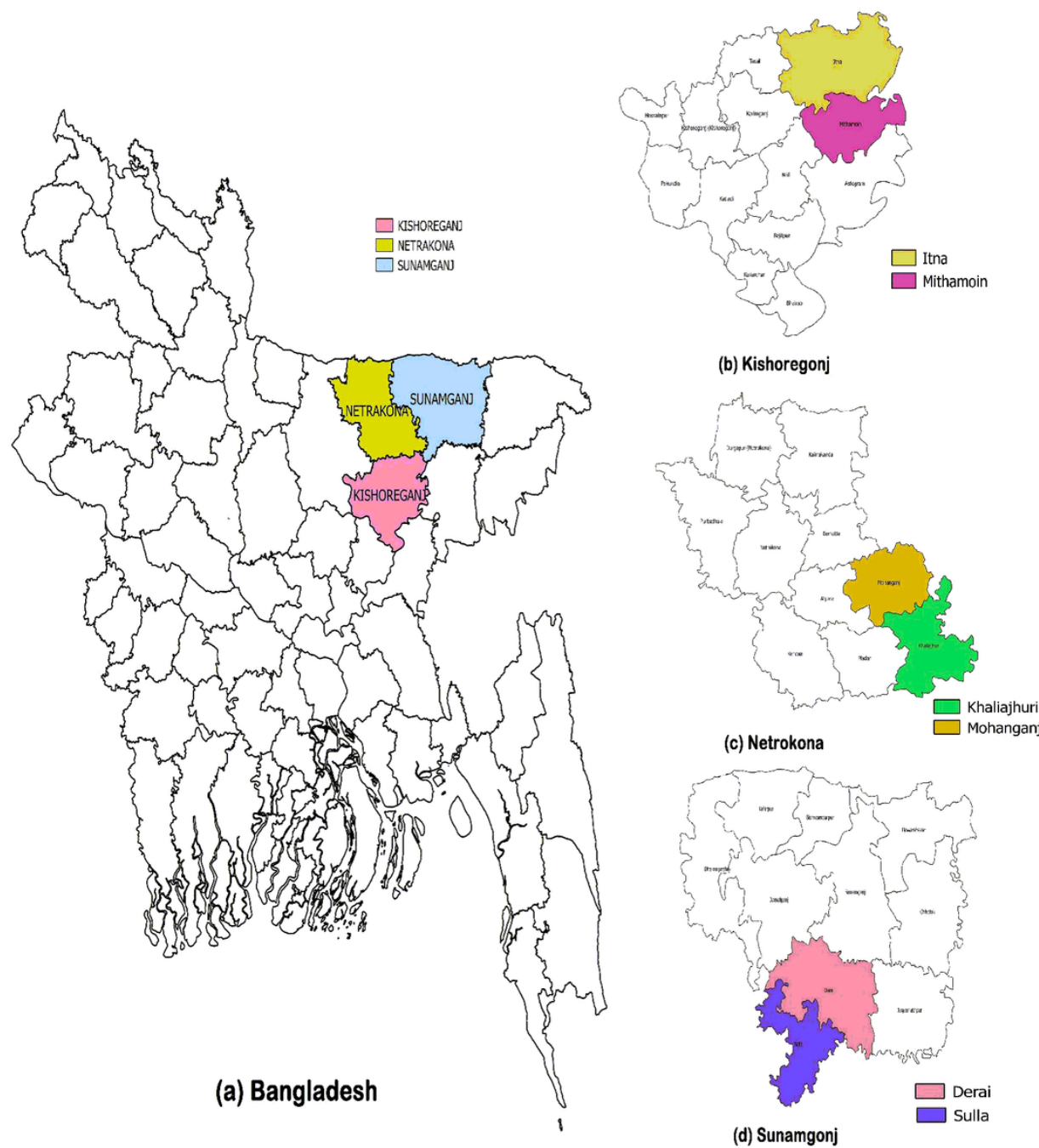

Figure 1

a) indicates the location of the study areas (three districts) in the Bangladesh map and (b-d) indicates the selected six upazilas from three districts. 


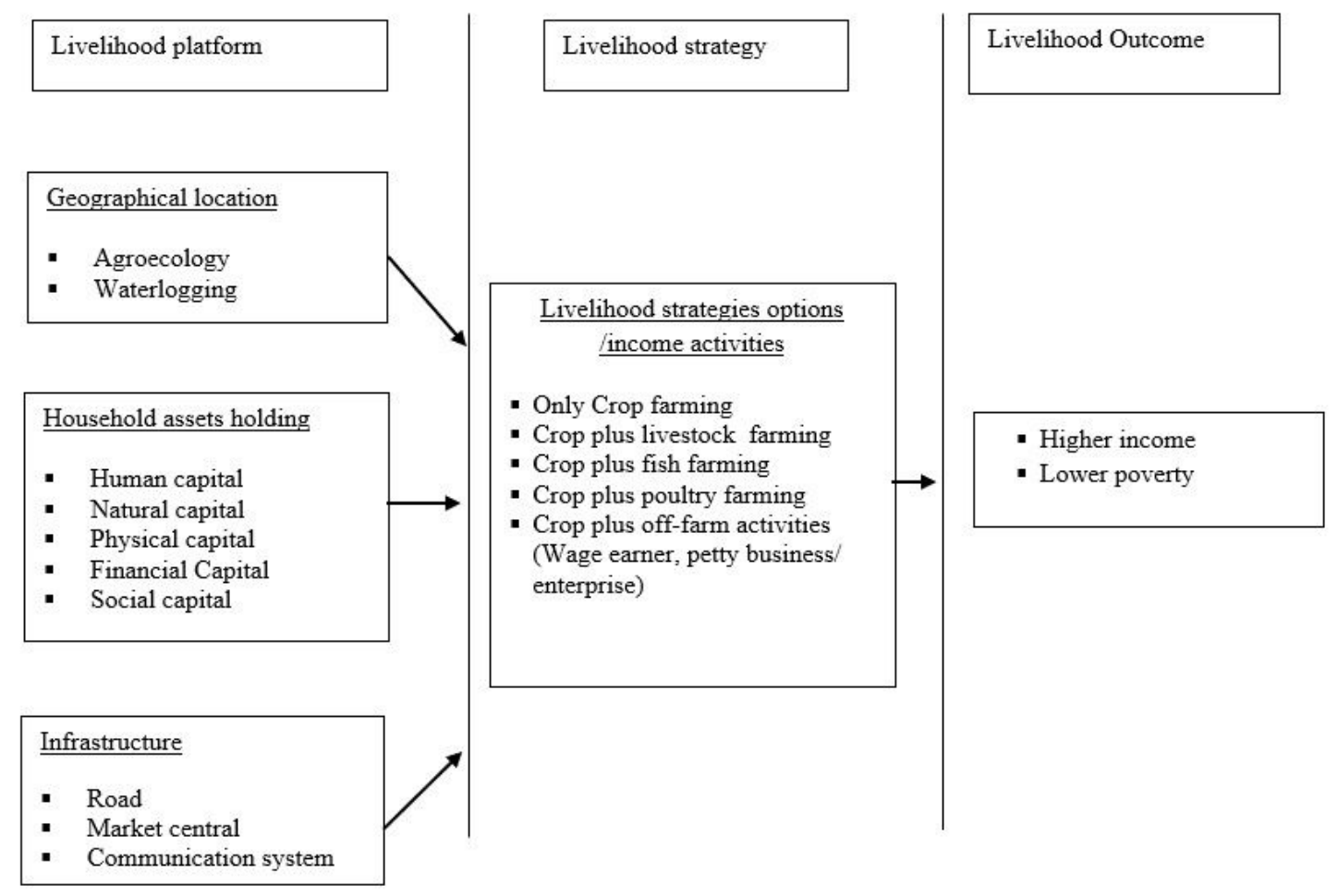

(Source: Adopted from Khatiwada et al. 2017; Carney1998; Soltani et al. 2012 and Babulo et al. 2008)

\section{Figure 2}

Conceptual sustainable livelihood framework (SLF)

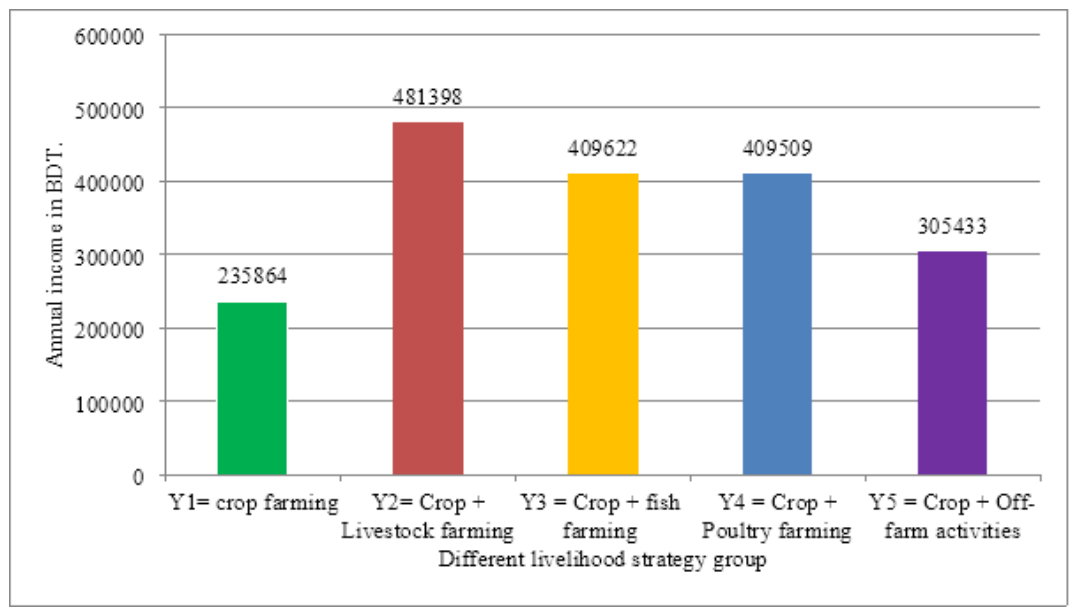

Figure 3

Source of income by different livelihood strategies group

\section{Supplementary Files}

This is a list of supplementary files associated with this preprint. Click to download.

- Appendix.docx 